\title{
MORPHOLOGY, COMPOSITION AND STRUCTURE OF LOW-TEMPERATURE P4/nnc HIGH-FLUORINE VESUVIANITE WHISKERS FROM POLAR YAKUTIA, RUSSIA
}

\author{
EVGENY V. GALUSKIN $\$$ \\ Faculty of Earth Sciences, Department of Geochemistry, Mineralogy and Petrography, \\ University of Silesia, Bedzińska 60, 41-200 Sosnowiec, Poland
}

ThOMAs ARMBRUSTER ${ }^{\S}$ AND ANNA MALSY

Laboratory for Chemical and Mineralogical Crystallography, University of Bern, Freiestr. 3, CH-3012 Bern, Switzerland

\author{
IRINA O. GALUSKINA ${ }^{\S}$
}

Faculty of Earth Sciences, Department of Geochemistry, Mineralogy and Petrography, University of Silesia, Będzinska 60, 41-200 Sosnowiec, Poland

MACIEJ SITARZ

University of Mining and Metallurgy, Mickiewicza 30, 30-059 Cracow, Poland

\begin{abstract}
Whiskers and needles of F-rich vesuvianite were found together with diopside in cavities of an altered magnesian skarn in the Tas-Khayakhtakh Mountains of Polar Yakutia, in Russia. The acicular crystals are strongly zoned and formed between two generations of diopside. The chemical composition of the vesuvianite whiskers is more homogeneous and resembles that of the outermost rim of the vesuvianite needles. In the last stage, fluorapophyllite, prehnite, titanite, calcite and quartz overgrew vesuvianite. Whiskers of vesuvianite crystallized at low activity of $\mathrm{CO}_{2}$ and $\mathrm{P}-\mathrm{T}$ conditions corresponding to the prehnitepumpellyite facies. Single-crystal X-ray refinements of the structure of three vesuvianite whiskers, for which electron-microprobe data also were collected, revealed $P 4 / n n c$ space-group symmetry and $(\mathrm{F}, \mathrm{Cl})$ substitution at $\mathrm{O}(10)$ within disordered strings running parallel to the four-fold axis. In addition, there is partial substitution of $\mathrm{F}$ at $\mathrm{O}(11)$, usually occupied by $\mathrm{OH}$ in lowtemperature vesuvianite. The high symmetry $(P 4 / n n c)$ in low-temperature $\left(<350^{\circ} \mathrm{C}\right)$ whiskers of vesuvianite adds evidence that the degree of string order is determined not only by the temperature of crystallization, as hitherto assumed, but also by the prevailing composition of the fluid and the regime of crystal growth leading to substitutions that disturb intra-rod order and particularly long-range rod order. Long-range rod order leads to reduced symmetry $(P 4 / n$ or $P 4 n c)$, typical of vesuvianite crystallized at low temperature in rodingites. Vesuvianite whiskers formed in a kinetic regime where the growth rates were selectively influenced by surface-active substances poisoning the prism faces. Growth of faces in vesuvianite whiskers is explained by a tangential layer-by-layer mechanism without participation of a central screw dislocation.
\end{abstract}

Keywords: low-temperature vesuvianite, whisker, fluorine, composition, crystal structure, crystal growth, infrared spectra, Yakutia, Russia.

\section{SOMMAIRE}

Nous avons découvert des trichites et des aiguilles de vésuvianite riche en fluor avec diopside dans des cavités d'un skarn magnésien altéré dans les montagnes Tas-Khayakhtakh, en Yakoutie polaire, en Russie. Les cristaux aciculaires sont fortement zonés et se sont formés entre deux générations de diopside. La composition chimique de la vésuvianite trichitique est plus homogène, et ressemble à celle de la bordure des aiguilles de vésuvianite. Au stade ultime de croissance, fluorapophyllite, prehnite, titanite, calcite et quartz ont englobé la vésuvianite. Les trichites de vésuvianite ont cristallisé à une faible activité de $\mathrm{CO}_{2}$ à des conditions de $\mathrm{P}$ et de $\mathrm{T}$ correspondant au faciès prehnite-pumpellyite. Des affinements de la structure par diffraction $\mathrm{X}$ sur trois monocristaux trichitiques, pour lesquels nous possédons des données sur la composition obtenues par analyses à la microsonde

§ E-mail addresses: galuskin@us.edu.pl, thomas.armbruster@krist.unibe.ch,irina@wnoz.us.edu.pl,msitarz@agh.edu.pl 
électronique, révèlent une symétrie $P 4 / n n c$ et une substitution de $(\mathrm{F}, \mathrm{Cl})$ au site $\mathrm{O}(10)$ au sein d'agencements linéaires ou tiges désordonnés le long de l'axe d'ordre 4. De plus, il y a substitution partielle de $\mathrm{F}$ au site $\mathrm{O}(11)$, où loge normalement un groupe $\mathrm{OH}$ dans la vésuvianite de basse température. La symétrie élevée $(P 4 / n n c)$ des trichites formées à faible température $\left(<350^{\circ} \mathrm{C}\right)$ viendrait renforcer l'hypothèse voulant que le degré d'ordre dans ces agencement linéaires dépend non seulement de la température de cristallisation, comme on l'avait supposé antérieurement, mais aussi de la composition de la phase fluide et des conditions de croissance cristalline menant à des substitutions qui dérangent l'ordre le long des tiges, et particulièrement qui entravent l'ordre à longue échelle. Une mise en ordre à longue échelle mène à une symétrie réduite $(P 4 / n$ ou $P 4 n c)$, typique de la vésuvianite cristallisée à faible température, dans les rodingites. Les trichites de vésuvianite se sont formées dans un milieu de croissance où les taux de croissance étaient sélectivement influencés par des substances empoisonant les faces prismatiques. La croissance des faces dans les trichites de vésuvianite serait due à un mécanisme tangentiel de croissance couche par couche sans la participation d'une dislocation vis centrale.

(Traduit par la Rédaction)

Mots-clés: vésuvianite de faible température, trichite, fluor, composition, structure cristalline, croissance cristalline, spectroscopie infra-rouge, Yakoutie, Russie.

\section{INTRODUCTION}

Minerals of the vesuvianite group occur not only in skarns, rodingites, and metamorphosed siliceous limestones, but also in altered syenites and hydrothermal veins (Chukhrov et al. 1972, Arem 1973, Groat et al. 1992a, 1998, Fitzgerald et al. 1992, Armbruster et al. 2002a). In skarns, vesuvianite usually develops prismatic or bipyramidal crystals with rather simple forms: $\{100\},\{110\},\{101\},\{001\}$ (Goldschmidt 1918, Lyakhovich 1954, Chukhrov et al. 1972). The crystal morphology is more complicated in rodingitic vesuvianite, which is commonly more acicular (Goldschmidt 1918, Chukhrov et al. 1972, Arem 1973, Antonova \& Goylo 1999). In this study, we describe the relation among morphology, crystal structure, and composition of whiskers of high-fluorine, high-symmetry, low-temperature vesuvianite from cavities of an altered magnesian skarn in the Tas-Khayakhtakh Mountains of Polar Yakutia, in Russia.

\section{BACKGROUND INFORMATION}

Filiform crystals up to a few ten $\mu \mathrm{m}$ across with a length-to-breadth ratio of 10-100:1 are defined as whiskers (Gevargizov 1977). Thicker elongate crystals and those below the length-to-breadth ratio of whiskers are termed acicular. As will be shown in this study, acicular vesuvianite displays zonal growth, whereas whiskers are homogeneous. The appearance of natural whiskers depends on growth conditions and mechanism of crystal growth (Maleev 1971, Bonev 1993, Bonev et al. 1985, Galuskin \& Winiarski 1997). Whiskers of pyroxenes and amphiboles are well known, and their one-dimensional growth is generally attributed to polymerization of $\mathrm{SiO}_{4}$ tetrahedra forming chains or bands (Maleev 1971, Galuskin \& Mokhov 1991, Armbruster et al. 2000c, 2002b). The structure of vesuvianite, in particular the string arrangement parallel to the four-fold axes (e.g., Armbruster \& Gnos 2000b), suggests formation of crys- tals elongate along $c$. However, there are no condensed chains of $\mathrm{SiO}_{4}$ tetrahedra in the vesuvianite structure, and thus whisker formation is structurally not expected.

The symmetry of vesuvianite is defined by its growth conditions and thermal history. Comparative structural investigations of vesuvianite of variable genesis lead to a distinction of high-temperature, high-symmetry tetragonal vesuvianite $\left(>350-400^{\circ} \mathrm{C}\right)$ with long-range disorder (space group $P 4 / n n c$ ), and low-temperature, low-symmetry vesuvianite $\left(<350-400^{\circ} \mathrm{C}\right.$, from rodingites) with specific long-range "string" order (space group $P 4 / n$ and $P 4 n c$ ) (Allen \& Burnham 1992, Armbruster \& Gnos 2000a, b). The low-temperature stability boundary of high-temperature vesuvianite in skarns is usually determined by the activity of $\mathrm{CO}_{2}$ and lies near $400^{\circ} \mathrm{C}$ (Plyusnina \& Likhoidov 1993). In contrast, in rodingites, vesuvianite forms below $320-350^{\circ} \mathrm{C}$ under conditions of the prehnite-pumpellyite down to the zeolite facies and very low activity of $\mathrm{CO}_{2}$ (Philpotts 1992, Spiridonov et al. 1996). High-temperature vesuvianite (from skarns) and low-temperature vesuvianite (from rodingites) are also different in terms of chemical composition. High-temperature dark brown and dark green vesuvianite is characterized by a high content of $\mathrm{Mg}, \mathrm{Fe}, \mathrm{B}$, and F (Shabynin 1974, Groat et al. 1992a, Fitzgerald et al. 1992). In comparison, low-temperature vesuvianite is characterized by a reduced content of $\mathrm{Mg}$ and a composition close to the hypothetical end-member in the system CMASH: $\mathrm{Ca}_{19} \mathrm{Al}_{12} \mathrm{MgSi}_{18} \mathrm{O}_{70}(\mathrm{OH})_{8}$ (Allen \& Burhnam 1992). Furthermore, low- and hightemperature vesuvianites are distinct in the occupancy of specific sites: $T(1)$ and $T(2)$ (mainly empty in lowtemperature vesuvianite) and $\mathrm{O}(10)$ and $\mathrm{O}(11)$ (mainly occupied by $\mathrm{OH}$ groups in low-temperature vesuvianite). Low-temperature vesuvianite generally displays the maximum possible $\mathrm{OH}$ content (up to $9 a p f u$, atoms per formula unit), whereas high-temperature vesuvianite commonly has relatively high contents of $\mathrm{F}$ replacing $\mathrm{OH}$ at $\mathrm{O}(10)$ and $\mathrm{O}(11)$ (Ohkawa 1994) or boron at $T(1)$ and $T(2)$ (Groat et al. 1996, 1998). 


\section{Geology and Sample Description}

Datolite-bearing skarns with cavities filled with vesuvianite whiskers have been found in the upper reaches of the Dokuchan River, in the Tas-Khayakhtakh Mountains (Polar Yakutia), $1 \mathrm{~km}$ from the contact with a granitic batholith (Galuskin \& Golovanova 1987, Fig.1). Early magnesian skarns formed by the replacement of Jurassic fine- and coarse-grained conglomerate horizons, especially the dolomite fragments (Fig. 1). Post- magmatic alteration of the early magnesian skarns led to formation of porous pyroxene-garnet rocks with abundant cavities coated by crystals of diopside, fluorapophyllite, prehnite, datolite, quartz and calcite. Fluorite, titanite, pyrite, chalcopyrite, sphalerite, apatite, arsenopyrite, and REE-bearing epidote are accessory minerals. The central part of the cavities is filled by finegrained calcite and fluorapophyllite or asbestiform tremolite or earthy microcline. Whiskers and needles of vesuvianite were discovered in small solution-cavities

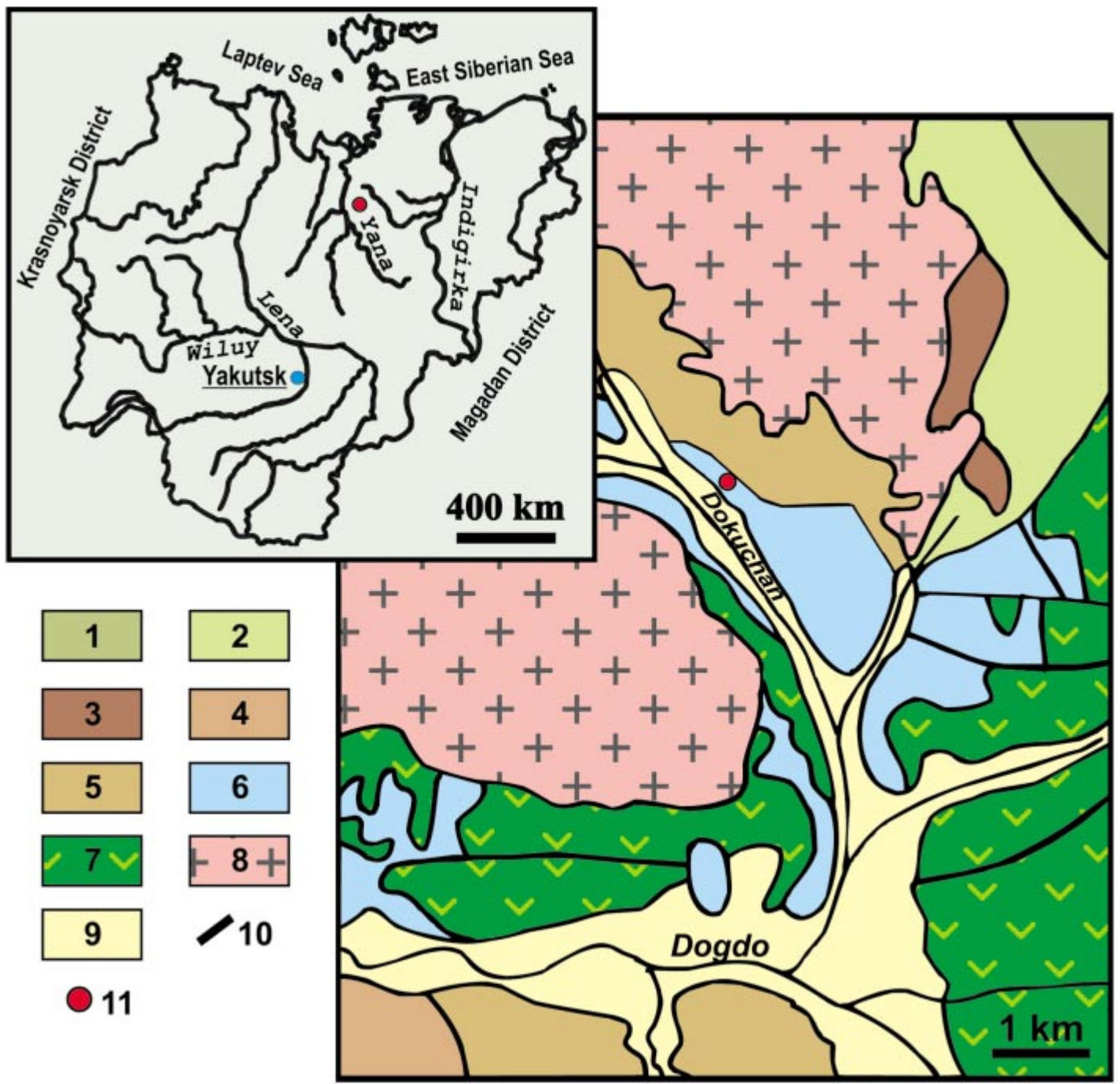

FIG. 1. Schematic map of the Republic of Sakha (Yakutia) and geological sketch-map of the area studied (Galuskin \& Mokhov 1991, modified). Units 1-5: dolomite, limestone: 1 Middle Ordovician, 2 Middle Silurian, 3 Lower Devonian, 4 Middle Devonian, 5 Upper Devonian; 6: Middle Jurassic terrigenous sedimentary rocks; 7: Upper Jurassic volcanic-sedimentary rocks; 8: Lower Cretaceous granites; 9: Quaternary alluvial deposits; 10: faults; 11: skarns with vesuvianite whiskers. 
with relics of ferrian grossular. Galuskin \& Mokhov (1991) developed a genetic model for skarn formation, based on different generations of diopside.

\section{EXPERIMENTAL METHODS}

The morphology of vesuvianite was studied using a FEI/Philips XL30 ESEM electron microscope (Environmental Scanning Electron Microscope) with EDAX analytical equipment operated at high-vacuum (HV) and low-vacuum (LV) conditions. Secondary Electron [SE (HV)] and Back-Scattered Electron [BSE (HV and LV, 0.2-0.4 Torr)] detectors were used to obtain images of vesuvianite. For work in the LV regime, non-coated samples were used.

Single-crystal X-ray data were collected with an Enraf-Nonius CAD4 diffractometer, using graphite monochromated MoK $\alpha$ X-radiation, for three whiskers of vesuvianite of different size and morphology (Ves 1, Ves 2, and Ves 4). Experimental details are given in Table 1. Cell dimensions were refined from the angular setting of 25 reflections with $15^{\circ}<\theta<25^{\circ}$. Intensity data were collected with $\omega$ scans of $1^{\circ} \times 0.35 \tan \theta$, allowing for a maximum exposure time of 300 seconds. Data reduction, including background and Lorenz polarization correction, was carried out with the SDP program system (Enraf-Nonius 1983). An empirical absorption-correction using the $\psi$-scan technique was applied.

The vesuvianite whiskers used for collection of Xray intensity data, together with additional acicular crystals and whiskers of vesuvianite, were analyzed with a Cameca SX-100 electron microprobe (Warsaw) oper-

\begin{tabular}{|c|c|c|c|}
\hline & Ves 1 & Ves 2 & Ves 4 \\
\hline$a[\AA]$ & $15.536(3)$ & $15.529(2)$ & $15.513(3)$ \\
\hline$c[A]$ & $11.781(3)$ & $11.772(2)$ & $11.778(2)$ \\
\hline$V\left[\AA^{3}\right]$ & $2844(2)$ & $2838.6(8)$ & $28.34(1)$ \\
\hline Crystal size $[\mathrm{mm}]$ & $0.038 \times 0.6$ & $0.036 \times 0.18$ & $0.02 \times 0.22$ \\
\hline Morphology & $\{100\}:\{110\} \approx 1: 1$ & $\{100\}:\{110\} \approx 4: 1$ & $\{100\}:\{110\} \approx 10: 1$ \\
\hline Space group & P4/nnc & P4innc & $P 4 / n n c$ \\
\hline $\mathrm{Z}$ & 2 & 2 & 2 \\
\hline Diffractometer & \multicolumn{3}{|c|}{ ENRAF-NONIUS CAD4 } \\
\hline Radiation & \multicolumn{3}{|c|}{$\operatorname{MoK} \alpha(\lambda 0.71069 \AA)$} \\
\hline \multirow[t]{3}{*}{ Index range } & $0 \leq h \leq 19$ & $0 \leq h \leq 18$ & $0 \leq h \leq 19$ \\
\hline & $0 \leq k \leq 19$ & $0 \leq k \leq 18$ & $0 \leq k \leq 19$ \\
\hline & $0 \leq l \leq 15$ & $0 \leq t \leq 13$ & $0 \leq l \leq 15$ \\
\hline Maximum $2 \theta$ & 53.92 & 49.91 & 53.94 \\
\hline Reflections collected & 3491 & 2835 & 3475 \\
\hline Unique reflections & 1561 & 1254 & 1553 \\
\hline Reflections $>2 \sigma(\mathrm{I})$ & 1094 & 742 & 809 \\
\hline Number of parameters & 165 & 160 & 160 \\
\hline$R_{t m t}$ & 0.0256 & 0.0413 & 0.0564 \\
\hline $\mathrm{R}_{\mathrm{o}}$ & 0.0345 & 0.0587 & 0.0824 \\
\hline Goof & 1.017 & 0.972 & 0.924 \\
\hline$R 1, \mathrm{I}>20$ & 0.0215 & 0.0282 & 0.0296 \\
\hline$R 1$, all data & 0.0524 & 0.0825 & 0.1078 \\
\hline $\mathrm{w} R 2\left(\right.$ on $\left.F^{2}\right)$ & 0.0554 & 0.0615 & 0.0656 \\
\hline
\end{tabular}

ated in the wavelength-dispersion mode. Measurements of concentrations of the main elements were performed at $15 \mathrm{kV}$ and $20 \mathrm{nA}$ for 20 seconds using natural standards. Concentrations of $\mathrm{F}$ and $\mathrm{B}$ at each point were measured at $5 \mathrm{kV}$ and $100 \mathrm{nA}$ for 50 seconds. For B, a PC2 analyzer crystal [Ni/C - Layered Synthetic Microstructure (LSM) crystal] was used with natural danburite as standard, whereas for F, a PC1 analyzer crystal (W/ Si LSM) was used, with synthetic fluorine-substituted phlogopite as standard. The concentrations of $\mathrm{B}$ and $\mathrm{F}$ were obtained from peak integrations. Experimental determination of background for the $\mathrm{B} K \alpha$ peak in vesuvianite and wiluite, and systematic measurements for chlorine on boron-free minerals (marialite, fluorapatite, tugtupite) allowed us to reduce the interference between $\mathrm{Cl}\left(L_{1}\right.$ and $\left.L_{n}\right)$ and B for chlorine concentrations less than $1 \%$ (McGee \& Anovitz 1996). Data were reduced using the $\phi(\rho Z)$ procedure of Pouchou \& Pichoir (1985).

The optical properties of vesuvianite were investigated in thin sections and immersion liquids using a polarizing microscope. The indices of refraction for whisker Ves 1 were $\varepsilon=1.706(1), \omega=1.711(2)$.

IR (infrared) powder spectra of vesuvianite were collected from $\mathrm{KBr}$ pellets at room temperature (resolution $4 \mathrm{~cm}^{-1}$ ) using a FTIR Digilab 60V (BioRad) spectrometer between 400 and $4000 \mathrm{~cm}^{-1}$. Spectra of whiskers and acicular crystals are qualitatively very similar.

\section{Morphology AND COMPOSITION OF WhisKers}

Vesuvianite forms aggregates of acicular crystals and whiskers assembled into incomplete spherulites and sheaf-like aggregates (Fig. 2a). Both forms of vesuvianite coexist in cavities (Figs. 2b-e). Usually, vesuvianite crystals form entangled, fibrous aggregates in the central part of the cavity and fill the space between early diopside crystals and grains of partially dissolved grossular (Fig. 2b). Whiskers of vesuvianite commonly are bent if they meet an obstacle during growth or they are deformed due to the load of overgrowing crystals such as apophyllite, quarz, titanite, and prehnite. This high elasticity is characteristic of whiskers and is not observed for acicular crystals (Figs. 2c, d, e). Vesuvianite whiskers and acicular crystals both penetrate diopside crystals (Figs. 2c, e), a relationship implying that vesuvianite formed between two late generations of diopside (Galuskin \& Mokhov 1991).

Acicular and whisker forms of vesuvianite are characterized by a combination of $\{100\}$ and $\{110\}$ prisms (Figs. 2c-f). Rough faces close to $\{001\}$ (Fig. 2f) usually form the tip of the whiskers. There is no evidence for a central screw dislocation, either in vesuvianite or in coeval diopside whiskers (Galuskin \& Mokhov 1991).

Results of electron-microprobe analyses of acicular vesuvianite plot in four fields in compositional diagrams, corresponding to the zonal growth of vesuvian- 
ite (Table 2, Fig. 3). Three zones are distinguished in the (001) cross-sections of relatively thick individual crystals $(>50 \mu \mathrm{m})$ forming the base of spherulites (Table 2, Figs. 2a, 3): 1) a central zone enriched in $\mathrm{Mg}$, $\mathrm{Fe}$ and $\mathrm{B}, 2)$ an intermediate zone in which $\mathrm{Ti}, \mathrm{Fe}$ and Ce contents increase, and 3) a rim zone in which $\mathrm{Ti}, \mathrm{Mg}$ and $\mathrm{Fe}$ contents decrease, and $\mathrm{Al}$ content increases.

In (100) cross-sections of acicular crystals, a fourth zone can be resolved (Table 2, Fig. 3), which is further enriched in $\mathrm{Al}, \mathrm{Mn}$, and $\mathrm{F}$, but depleted in Fe, Ti and $\mathrm{Mg}$. In back-scattered electron (BSE) images, vesuvianite whiskers seem rather homogeneous, and their composition corresponds to the composition of the fourth zone and, less commonly, to the composition of the third zone (Fig. 3, Table 2). For the third and fourth zones of the acicular crystals and also for the whiskers, a slight deficiency in the $X$ cations is apparent (Table 2). All zones are optically negative, with $2 V_{X}$ less than $5^{\circ}$.

The high content of $\mathrm{F}$, up to 3.7 atoms per formula unit (apfu), and increased content of $\mathrm{Cl}$, up to 0.6 apfu (Table 2, Fig. 3), are distinguishing features of both whiskers and acicular crystals of vesuvianite. Concerning the nature of the $Y$-site cations, vesuvianite whiskers are rather similar to vesuvianite from rodingites (Groat et al. 1992a, Fitzgerald et al. 1992, Antonova \& Goylo 1999). In vesuvianite and diopside whiskers

TABLE 2. COMPOSITION OF VESUVIANITE WHISKERS AND ACICULAR CRYSTALS FROM AN ALTERED SKARN, POLAR YAKUTIA, RUSSIA

\begin{tabular}{|c|c|c|c|c|c|c|c|c|c|c|c|c|c|}
\hline & \multicolumn{7}{|c|}{ acicular crystals (spherulite) } & \multicolumn{6}{|c|}{ single whiskers } \\
\hline & \multicolumn{3}{|c|}{ Direction [100] } & \multicolumn{4}{|c|}{ Direction [001] } & \multicolumn{2}{|c|}{ Ves $1(\Sigma 12)$} & \multicolumn{2}{|c|}{ Ves $2(\Sigma 13)$} & \multicolumn{2}{|c|}{ Ves $4(\Sigma 11)$} \\
\hline & center & middle & rim & base & middle & middle & edge & mean(st.dv) & range & mean(st.dv) & range & mean(st.dv) & range \\
\hline $\mathrm{SiO}_{2}$ wt. $\%$ & 35.82 & 35.06 & 36.12 & 36.23 & 36.11 & 36.34 & 36.80 & $36.27(0.36)$ & $35.72-36.76$ & $36.48(0.43)$ & $35.72-37.09$ & $36.49(0.22)$ & $36.17-37.05$ \\
\hline $\mathrm{SO}_{3}{ }^{2}$ & 0.07 & 0.06 & 0.04 & n.m. & n.m. & n.d. & n.m. & $0.09(0.03)$ & $0.03-0.16$ & & & & \\
\hline $\mathrm{TiO}_{2}$ & 0.17 & 2.11 & 0.77 & 0.09 & 2.55 & 1.11 & 0.36 & $1.15(0.28)$ & $0.37-1.83$ & $0.88(0.09)$ & $0.75-1.06$ & $0.48(0.09)$ & $0.39-0.62$ \\
\hline $\mathrm{B}_{2} \mathrm{O}_{3}^{2}$ & 1.28 & 0.26 & n.d. & 1.17 & 0.25 & n.d. & n.d. & $0.25(0.16)$ & $0.00-0.49$ & $0.29(0.15)$ & n.d. -0.68 & $0.21(0.21)$ & n.d. -0.95 \\
\hline $\mathrm{Al}_{2} \mathrm{O}_{3}$ & 16.26 & 15.42 & 17.19 & 16.19 & 14.98 & 16.96 & 19.37 & $17.33(0.41)$ & $16.21-19.36$ & $18.30(0.26)$ & $17.91-18.80$ & $19.12(0.23)$ & $18.73-19.36$ \\
\hline $\mathrm{Cr}_{2} \mathrm{O}_{3}$ & n.d. & 0.02 & 0.04 & n.d. & n.d. & 0.01 & n.d. & n.d. & & n.d. & & n.d. & \\
\hline $\mathrm{Ce}_{2} \mathrm{O}_{3}$ & n.d. & 0.11 & 0.04 & n.d. & 0.35 & 0.09 & n.d. & $0.12(0.07)$ & $0.00-0.20$ & n.d. & & n.d. & \\
\hline $\mathrm{MgO}$ & 2.45 & 2.16 & 1.62 & 2.09 & 1.99 & 2.03 & 1.26 & $1.67(0.28)$ & I.09-2.26 & $1.40(0.03)$ & $1.36-1.45$ & $1.18(0.09)$ & $1.09-1.34$ \\
\hline $\mathrm{CaO}$ & 35.57 & 34.81 & 35.57 & 35.54 & 35.23 & 35.6 & 35.60 & $35.61(0.18)$ & $35.28-35.88$ & $35.43(0.16)$ & $35.18-35.66$ & $35.69(0.17)$ & $35.31-35.92$ \\
\hline $\mathrm{MnO}$ & n.d. & 0.02 & 0.23 & 0.04 & 0.04 & 0.11 & 0.41 & $0.14(0.04)$ & $0.07-0.36$ & $0.15(0.11)$ & $0.09-0.21$ & $0.28(0.06)$ & $0.20-0.40$ \\
\hline $\mathrm{FeO}^{*}$ & 3.64 & 3.60 & 3.40 & 4.50 & 4.24 & 3.10 & 2.01 & $3.04(0.17)$ & $2.24-3.44$ & $2.72(0.11)$ & $2.53-2.89$ & $2.32(0.13)$ & $2.16-2.60$ \\
\hline $\mathrm{Na}_{2} \mathrm{O}$ & 0.02 & 0.02 & 0.04 & n.d. & 0.09 & 0.06 & 0.12 & $0.06(0.04)$ & $0.04-0.09$ & $0.07(0.01)$ & $0.05-0.09$ & $0.08(0.03)$ & $0.06-0.11$ \\
\hline $\mathrm{F}^{2}$ & 1.27 & 1.95 & 0.99 & 1.29 & 1.29 & 1.95 & 2.33 & $1.97(0.09)$ & $1.71-2.22$ & $2.01(0.06)$ & $1.87-2.09$ & $2.04(0.26)$ & $1.35-2.21$ \\
\hline $\mathrm{Cl}$ & 0.33 & 0.47 & 0.50 & 0.28 & 0.51 & 0.59 & 0.40 & $0.52(0.14)$ & $0.31-0.72$ & $0.60(0.06)$ & $0.54-0.72$ & $0.45(0.08)$ & $0.34-0.57$ \\
\hline $\mathrm{H}_{2} \mathrm{O}^{* *}$ & 1.60 & 1.48 & 2.22 & 1.44 & 1.76 & 1.60 & 0.92 & 1.37 & & 0.86 & & 1.12 & \\
\hline$-\mathrm{O}=\mathrm{F}+\mathrm{Cl}$ & 0.61 & 0.93 & 0.53 & 0.61 & 0.66 & 0.96 & 1.08 & 0.95 & & 0.99 & & 0.97 & \\
\hline Total & 97.87 & 96.62 & 98.24 & 98.25 & $98.83^{\mathrm{X}}$ & 98.59 & 98.50 & 98.64 & & 98.20 & & 98.49 & \\
\hline Са apfu & 18.98 & 18.96 & 18.95 & 19.00 & 18.85 & 18.92 & 18.88 & 18.92 & & 18.93 & & 18.92 & \\
\hline $\mathrm{Na}$ & 0.02 & 0.02 & 0.04 & & 0.09 & 0.06 & 0.12 & 0.06 & & 0.07 & & 0.08 & \\
\hline $\mathrm{Ce}^{3+}$ & & 0.02 & 0.01 & & 0.06 & 0.02 & & 0.02 & & & & & \\
\hline$X$ & 19 & 19 & 19 & 19 & 19 & 19 & 19 & 19 & & 19 & & 19 & \\
\hline$X^{*}$ & $(19.12)$ & $(19.15)$ & (19.03) & $(18.92)$ & $(18.96)$ & $(18.97)$ & $(18.77)$ & $(18.98)$ & & $(18.80)$ & & $(18.94)$ & \\
\hline $\mathrm{Ti}^{4+}$ & 0.06 & 0.81 & 0.29 & 0.03 & 0.96 & 0.41 & 0.13 & 0.43 & & 0.33 & & 0.18 & \\
\hline $\mathrm{Al}$ & 9.55 & 9.24 & 10.07 & 9.52 & 8.82 & 9.92 & 11.30 & 10.13 & & 10.75 & & 11.15 & \\
\hline $\mathrm{Cr}$ & & 0.01 & 0.02 & & & & & & & & & & \\
\hline $\mathrm{Mg}$ & 1.82 & 1.64 & 1.20 & 1.55 & 1.48 & 1.50 & 0.93 & 1.23 & & 1.04 & & 0.87 & \\
\hline $\mathrm{Mn}^{2+}$ & & 0.01 & 0.10 & 0.02 & 0.02 & 0.05 & 0.17 & 0.06 & & 0.06 & & 0.12 & \\
\hline $\mathrm{Fe}^{2+}$ & 1.52 & 1.53 & 1.41 & 1.88 & 1.77 & 1.29 & 0.83 & 1.26 & & 1.13 & & 0.96 & \\
\hline$Y$ & 12.95 & 13.23 & 13.09 & 13.00 & $13.08^{\mathrm{X}}$ & 13.17 & 13.37 & 13.11 & & 13.32 & & 13.28 & \\
\hline$\vec{Y}$ & (13.04) & $(13.34)$ & (13.11) & (12.94) & $(13.05)$ & (13.15) & $(13.21)$ & $(13.10)$ & & $(13.18)$ & & (13.24) & \\
\hline $\mathrm{Si}$ & 17.84 & 17.82 & 17.96 & 18.08 & 18.04 & 18.03 & 18.22 & 17.99 & & 18.19 & & 18.06 & \\
\hline$S^{6+}$ & 0.03 & 0.02 & 0.01 & - & - & - & - & 0.03 & & - & & - & \\
\hline$Z$ & 17.87 & 17.85 & 17.97 & 18.08 & 18.04 & 18.03 & 18.22 & 18.02 & & 18.19 & & 18.06 & \\
\hline $\mathrm{B}^{3+} / T$ & 1.10 & 0.23 & - & 1.01 & 0.22 & - & - & 0.21 & & 0.25 & & 0.18 & \\
\hline $\mathrm{OH}$ & 5.31 & 5.02 & 7.35 & 4.79 & 5.86 & 5.29 & 3.04 & 4.53 & & 2.86 & & 3.70 & \\
\hline $\mathrm{F}$ & 2.00 & 3.14 & 1.56 & 2.04 & 2.04 & 3.06 & 3.65 & 3.09 & & 3.17 & & 3.19 & \\
\hline $\mathrm{Cl}$ & 0.28 & 0.40 & 0.42 & 0.24 & 0.43 & 0.50 & 0.34 & 0.44 & & 0.51 & & 0.38 & \\
\hline
\end{tabular}

$\mathrm{X}^{*}, \mathrm{Y}^{*}$ : normalized on $18 \mathrm{Si}$ atoms per formula unit $(\mathrm{apfu}){ }^{*}$ all $\mathrm{Fe}$ as $\mathrm{Fe}^{2+},{ }^{* *}$ calculated on charge balance, ${ }^{\mathrm{x}}$ in total $0.10 \% \mathrm{CuO}$, and $0.04 \mathrm{Cu}{ }^{2+}$ apfu. The number of atoms is calculated on the basis of $78(\mathrm{O}+\mathrm{F}+\mathrm{Cl})$ and normalized on $19(\mathrm{Ca}+\mathrm{Na}+\mathrm{Ce})$ apfu. 

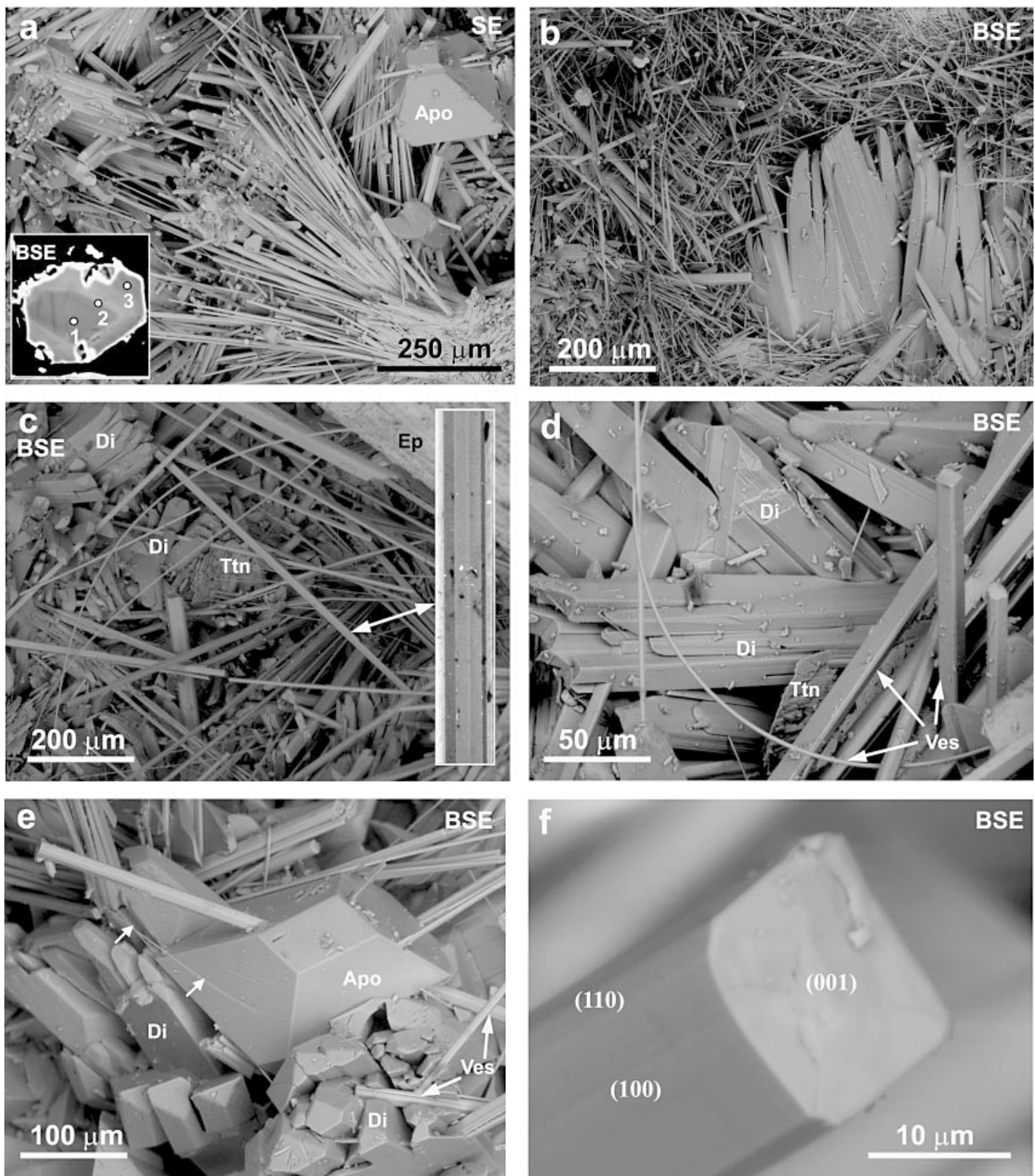

FIG. 2. Morphology of vesuvianite from Polar Yakutia (SE, BSE: type of electron-image detector used). a. Sheaf-like aggregate of acicular crystals and whiskers of vesuvianite, the $(001)$ section of crystal base $(0.08 \mathrm{~mm})$ with points of microprobe analyses indicated in inset in lower left (Table 2). b. Small cavity filled with entangled fibrous aggregates of vesuvianite. c. Curved and slender whiskers of vesuvianite. The arrow indicates the whisker used for the structural investigation; a fragment of this whisker (Ves 1, thickness $0.036 \mathrm{~mm}$ ) is shown on the right side in the window. It is formed by $\{100\}$ and $\{110\}$ prisms. d. Acicular crystals of vesuvianite and vesuvianite whiskers. e. Fluorapophyllite crystal growing on acicular crystal of vesuvianite; whiskers of vesuvianite less than $1 \mu \mathrm{m}$ in diameter are shown by arrows. f. Tip of filiform crystal of vesuvianite. Symbols: Apo fluorapophyllite, Di diopside, Ttn titanite, Ep epidote, Ves vesuvianite. 

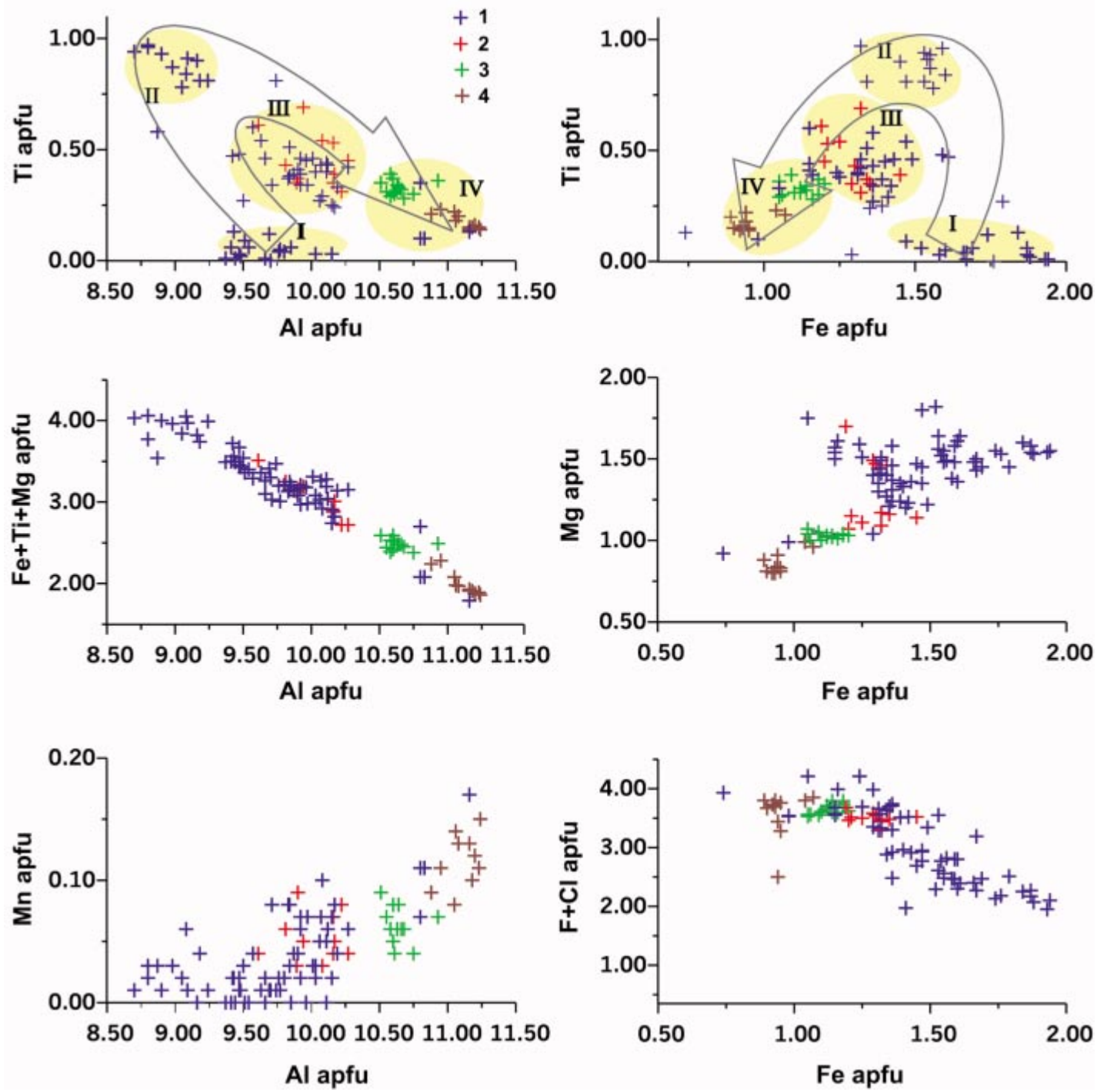

FIG. 3. Results of electron-microprobe analyses of acicular crystals (1) and whiskers (2: Ves 1, 3: Ves 2, 4: Ves 4) of vesuvianite plotted in composition diagrams. I-IV: zones in acicular crystals. Arrow indicates the trend of compositional change.

(Galuskin \& Mokhov 1991), the Mn content significantly increases toward the rim of the crystals. Furthermore, the composition of both minerals approaches that of the "ideal" end-members, $\mathrm{Ca}_{19} \mathrm{Al}_{11} \mathrm{MgFeSi}_{18} \mathrm{O}_{68}$ $(\mathrm{OH}, \mathrm{F}, \mathrm{O}, \mathrm{Cl})_{10}$ and $\mathrm{CaMgSi}_{2} \mathrm{O}_{6}$, respectively (Table 2, Fig. 3, and Galuskin \& Mokhov 1991).

The composition of vesuvianite whiskers, except for the high fluorine content, corresponds to that of low- symmetry and low-temperature vesuvianite, which is consistent with the mineral association. However, the FTIR spectrum of vesuvianite whiskers (Fig. 4) (Żabiński \& Paluszkiewicz 1994, Groat et al. 1995, Paluszkiewicz \& Żabiński 1999) and the crystal-structure refinements given below confirm that the whiskers consist of the high-symmetry (skarn type) vesuvianite, characterized by the space group $P 4 / n n c$. 


\section{Crystal Structure of Vesuvianite Whiskers}

\section{Structure refinement}

Special care was taken to check the intensity of reflections violating P4/nnc symmetry. Only for crystal Ves 1 was weak but significant intensity found for the reflection 014 and its symmetry equivalents $\left[\mathrm{I}_{014}<\right.$ $5 \sigma(\mathrm{I})]$. Reflections of the $0 k l$ type with $k+l=2 n+1$ violate the $n$ glide plane in (100) and may be indicative of space group $P 4 / n$. However, the presence of only one weak forbidden reflection does not justify assignment of a lower symmetry.

Structure solution and refinement were performed with scattering factors for neutral atoms and the programs SHELXS and SHELXL-97 (Sheldrick 1997). The labeling of sites corresponds to that of Groat et al. (1992a, b). In addition, for the sake of clarity, partially occupied cation positions in the strings running parallel to the 4-fold axes are emphasized by addition of a prime: $X^{\prime}(4)$ and $Y^{\prime}(1)$. The assignment of atoms was guided by compositional results, bond distances, and the observed scattering power. Only Ca was assigned to $X(1)$, $X(2)$, and $X(3)$, whereas $(\mathrm{Ca}+\mathrm{Na})$ was attributed to $X^{\prime}(4)$. Octahedron $Y(2)$ is entirely occupied by $\mathrm{Al}$, whereas $Y(3)$ has additional $\mathrm{Fe}, \mathrm{Mg}$, and Ti. Minor $\mathrm{Mg}$ and $\mathrm{Ti}$ were fixed at $Y(3)$ according to the electron-microprobe results. In order to check the reliability of this assignment, the $\mathrm{Al}$ and $\mathrm{Fe}$ content at $Y(3)$ was refined for comparison with the analytical data. Atom $Y^{\prime}(1)$, at the center of the five-coordinated square pyramid, is dominated by $\mathrm{Fe}$. The $\mathrm{O}(10)$ site is strongly smeared out along the $c$ axis and was therefore split into two positions, O10A and O10B (Groat et al. 1992b, Ohkawa 1994). Furthermore, Groat et al. (1992b) provided convincing evidence that $\mathrm{O}(10)$ cannot be more than $50 \%$ occupied by $(\mathrm{OH}+\mathrm{F})$. For this reason, $0.5 \mathrm{O}$ was assigned to $\mathrm{O}(10 \mathrm{~A})$, and $0.5(\mathrm{~F}+\mathrm{Cl})$ was assigned to $\mathrm{O}(10 \mathrm{~B})$. Because IR absorptions between 3200 and $3000 \mathrm{~cm}^{-1}$ are very weak (Fig. 4), OH occupancy at $\mathrm{O}(10)$ can be neglected (Groat et al. 1995). For crystal Ves 1, the $\mathrm{F}: \mathrm{Cl}$ ratio at $\mathrm{O}(10 \mathrm{~B})$ was refined, whereas for

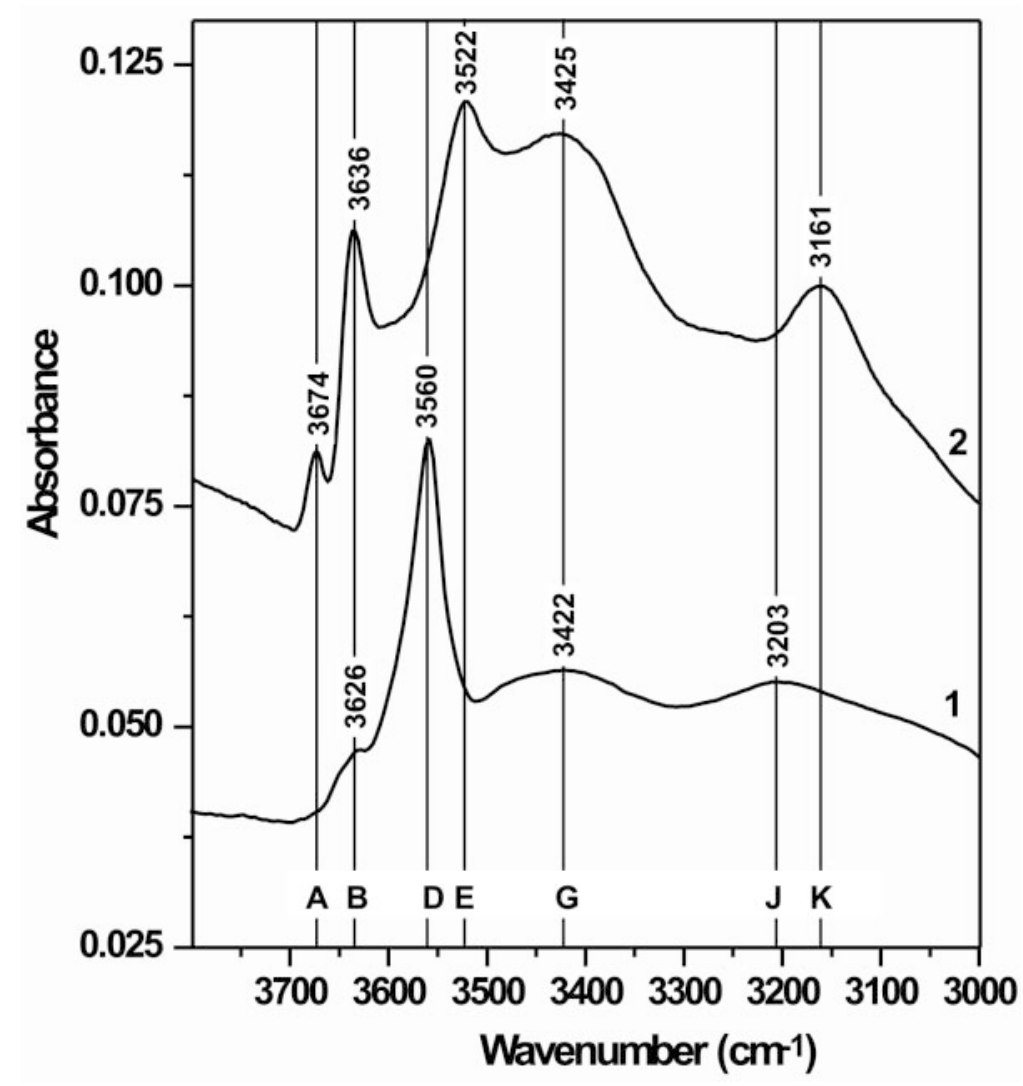

FIG. 4. FTIR spectra. 1: vesuvianite whiskers from Polar Yakutia; 2: vesuvianite from rodingites of Urals. The bands are labeled using the convention of Groat et al. (1995). 
crystals Ves 2 and Ves 4, Cl determined by electronmicroprobe analysis was assigned to $\mathrm{O}(10 \mathrm{~B})$, and the remainder at that site was presumed to be $F$. For crystal Ves 1 , the $(\mathrm{O}, \mathrm{F})$ population at $\mathrm{O}(11)$ (in spite of the similarity in scattering power) was refined, leading to 2.88(5) $p f u \mathrm{~F}$ [including $\mathrm{F}$ at $\mathrm{O}(10)$ ], in good agreement with $3.1 \mathrm{pfu} \mathrm{F}$ determined by electron-microprobe analysis. In addition, the assumption of significant $\mathrm{F}$ at $\mathrm{O}(11)$ increased the corresponding displacement parameter to a similar value as observed for other $\mathrm{O}$ sites. The $\mathrm{F}$ content at $\mathrm{O}(11)$ for crystals Ves 2 and Ves 4 was fixed according to the analytical results because the lower-quality data did not allow refinement of the $(\mathrm{O}$, F) population. The proton position close to $\mathrm{O}(11)$ was extracted from subsequent difference-Fourier maps, and the $\mathrm{O}(11)-\mathrm{H}(11)$ distance was constrained to be $0.95(5)$ $\AA$. Only for crystal Ves 1 did difference-Fourier maps display also significant electron-density at the interstitial site $T(1)$, determined by Groat et al. $(1994,1996)$ to be partially occupied by either excess $Y$-type cations or boron. $\mathrm{Al}$ (as dummy cation) was assigned to $T(1)$, and the population was refined with a fixed displacementparameter. Finally, a weak negative peak in electron density was observed in the center of the orthosilicate group $[\mathrm{Z}(1)]$, and the Si occupancy at $\mathrm{Z}(1)$ was refined, allowing for vacancies.

Atom coordinates and site occupancies are given in Tables 3a-c. Anisotropic displacement parameters are given in Tables $4 \mathrm{a}-\mathrm{c}$, and selected interatomic distances are summarized in Table 5. Tables of structure factors

TABLE 3a. POSITIONAL PARAMETERS OF ATOMS, SITE POPULATIONS, AND $B_{\text {eq }}$ VALUES FOR VESUVIANITE WHISKER Ves1

\begin{tabular}{|c|c|c|c|c|c|}
\hline atom & occupancy & $x / a$ & $y / b$ & $z / c$ & $B_{\mathrm{eq}[}\left[\AA^{2}\right]$ \\
\hline$Z(1)$ & $0.955(6) \mathrm{Si}$ & $3 / 4$ & $1 / 4$ & 0 & $0.36(2)$ \\
\hline$Z(2)$ & $\mathrm{Si}$ & $0.54086(4)$ & $0.18095(4)$ & $0.87130(5)$ & $0.50(1)$ \\
\hline$Z(3)$ & $\mathrm{Si}$ & $0.65062(4)$ & $-0.08243(4)$ & $0.63537(5)$ & $0.59(1)$ \\
\hline$X(1)$ & $\mathrm{Ca}$ & $3 / 4$ & $1 / 4$ & $3 / 4$ & $0.73(2)$ \\
\hline$X(2)$ & $\mathrm{Ca}$ & $0.68911(3)$ & $0.04353(3)$ & $.87969(4)$ & $0.643(8)$ \\
\hline$X(3)$ & $\mathrm{Ca}$ & $0.40087(3)$ & $0.17881(3)$ & $0.61380(4)$ & $1.002(8)$ \\
\hline$X^{\prime}(4)$ & $0.46 \mathrm{Ca}+0.04 \mathrm{Na}$ & $3 / 4$ & $-1 / 4$ & $0.8612(2)$ & $1.02(3)$ \\
\hline$Y(1)$ & $0.5 \mathrm{Fe}$ & $3 / 4$ & $-1 / 4$ & $0.9410(2)$ & $1.88(4)$ \\
\hline$Y(2)$ & $\mathrm{Al}$ & $1 / 2$ & 0 & $1 / 2$ & $0.55(1)$ \\
\hline \multirow[t]{2}{*}{$Y(3)$} & $0.750(3) \mathrm{Al}+0$ & & & & \\
\hline & $+0.155 \mathrm{Mg}+0$ & $0.61247(4)$ & $0.37918(4)$ & $0.87343(6)$ & $0.54(1)$ \\
\hline$O(1)$ & & $0.7196(1)$ & $0.3275(1)$ & $0.9143(1)$ & $0.67(3)$ \\
\hline$O(2)$ & & $0.6171(1)$ & $0.1597(1)$ & $0.7791(1)$ & $0.72(3)$ \\
\hline$O(3)$ & & $0.5495(1)$ & $0.2785(1)$ & $0.9240(1)$ & $0.61(2)$ \\
\hline$O(4)$ & & $0.5623(1)$ & $0.1066(1)$ & $0.9703(1)$ & $0.65(3)$ \\
\hline$O(5)$ & & $0.6700(1)$ & $0.0157(1)$ & $0.6787(1)$ & $0.79(3)$ \\
\hline$O(6)$ & & $0.7289(1)$ & $-0.1167(1)$ & $0.5593(1)$ & $1.15(3)$ \\
\hline$O(7)$ & & $0.4440(1)$ & $0.1743(1)$ & $0.8225(2)$ & $0.84(3)$ \\
\hline$O(8)$ & & $0.5906(1)$ & $-0.0609(1)$ & $0.9337(1)$ & $0.71(3)$ \\
\hline$O(9)$ & & $0.6436(1)$ & $-0,1436(1)$ & $3 / 4$ & $0.90(3)$ \\
\hline $\mathrm{O}(10 \mathrm{~A})$ & 0.50 & $3 / 4$ & $-1 / 4$ & $0.111(1)$ & $2.7(2)$ \\
\hline$O(10 B)$ & $0.216(8) \mathrm{C}$ & $3 / 4$ & $-1 / 4$ & $0.1633(9)$ & $2.9(2)$ \\
\hline$O(11)$ & $0.289(6) \mathrm{F}+0.7110$ & $0.4374(1)$ & $-0.0051(1)$ & $0.8643(1)$ & $0.81(3)$ \\
\hline $\mathrm{H}(11)$ & $\underline{0.711 \mathrm{H}}$ & $0.457(4)$ & $0.013(4)$ & $0.809(4)$ & $3.95^{*}$ \\
\hline$T(1)$ & $0.016(3) \mathrm{Al}$ & $0.440(3)$ & $0.060(3)$ & $3 / 4$ & $0.79^{*}$ \\
\hline
\end{tabular}

refined formula: $\mathrm{Ca}_{18.92} \mathrm{Na}_{0,08}\left(\mathrm{Al}_{10} \mathrm{Fe}_{133} \mathrm{Mg}_{1.24} \mathrm{Ti}_{0.43}\right) \mathrm{Si}_{17.91} \mathrm{O}_{69}(\mathrm{OH})_{5,71} \mathrm{~F}_{2,855} \mathrm{Cl}_{0.435}$ Note: $B_{\mathrm{eq}}$ values shown with an asterisk were fixed in the refinement. Underlined occupants were fixed. and Tables 4a-c are available from The Depository of Unpublished Data, CISTI, National Research Council, Ottawa, Ontario K1A 0S2, Canada.

TABLE 3b. POSTIONAL PARAMETERS OF ATOMS, SITE POPULATIONS, AND $B_{\mathrm{eq}}$ VALUES FOR VESUVIANITE WHISKER Ves2

\begin{tabular}{|c|c|c|c|c|c|}
\hline atom & occupancy & $x / a$ & $y^{\prime} b$ & $z / c$ & $B_{\text {eq }}\left[\AA^{2}\right]$ \\
\hline$Z(1)$ & $0.948(8) \mathrm{Si}$ & $3 / 4$ & $1 / 4$ & 0 & $0.25(3)$ \\
\hline$Z(2)$ & Si & $0.54095(6)$ & $0.18100(7)$ & $0.8712(1)$ & $0.52(2)$ \\
\hline$Z(3)$ & $\mathrm{Si}$ & $0.65064(6)$ & $-0.08227(7)$ & $0.63500(9)$ & $0.60(2)$ \\
\hline$X(1)$ & $\mathrm{Ca}$ & $3 / 4$ & $1 / 4$ & $3 / 4$ & $0.76(3)$ \\
\hline$X(2)$ & $\mathrm{Ca}$ & $0.68884(5)$ & $0.04336(5)$ & $0.87960(8)$ & $0.66(1)$ \\
\hline$X(3)$ & $\mathrm{Ca}$ & $0.40146(5)$ & $0.17832(5)$ & $0.61405(7)$ & $1.00(1)$ \\
\hline$X(4)$ & $0.46 \mathrm{Ca}+0.04 \mathrm{Na}$ & $3 / 4$ & $-1 / 4$ & $0.8627(4)$ & $1.37(7)$ \\
\hline$Y(1)$ & $0.5 \mathrm{Fe}$ & $3 / 4$ & $-1 / 4$ & $0.9377(4)$ & $1.95(6)$ \\
\hline$Y(2)$ & $\mathrm{Al}$ & $1 / 2$ & 0 & $1 / 2$ & $0.60(3)$ \\
\hline \multirow[t]{2}{*}{$Y(3)$} & $0.800(5) \mathrm{Al}+0.030(5) \mathrm{Fe}$ & & & & \\
\hline & $+0.129 \mathrm{Mg}+0.04125 \mathrm{Ti}$ & $0.61260(7)$ & $0.37902(6)$ & $0.8736(1)$ & $0.50(2)$ \\
\hline$O(1)$ & & $0.7197(2)$ & $0.3275(2)$ & $0.9147(2)$ & $0.69(5)$ \\
\hline$O(2)$ & & $0.6169(2)$ & $0.1597(2)$ & $0.7783(2)$ & $0.73(4)$ \\
\hline$O(3)$ & & $0.5497(2)$ & $0.2786(2)$ & $0,9237(2)$ & $0.64(4)$ \\
\hline$O(4)$ & & $0.5622(2)$ & $0.1066(2)$ & $0.9699(2)$ & $0.65(5)$ \\
\hline$O(5)$ & & $0.6702(2)$ & $0.0156(2)$ & $0.6783(2)$ & $0.84(5)$ \\
\hline$O(6)$ & & $0.7289(2)$ & $-0.1172(2)$ & $0.5599(2)$ & $1.26(5)$ \\
\hline$O(7)$ & & $0.4443(2)$ & $0.1745(2)$ & $0.8226(3)$ & $0.77(5)$ \\
\hline$O(8)$ & & $0.5903(2)$ & $-0.0607(2)$ & $0.9345(2)$ & $0.66(4)$ \\
\hline$O(9)$ & & $0.6431(2)$ & $-0.1431(2)$ & $3 / 4$ & $0.97(5)$ \\
\hline$O(10 \mathrm{~A})$ & 0.50 & $3 / 4$ & $-1 / 4$ & $0.103(2)$ & $2.0(3)$ \\
\hline$O(10 B)$ & 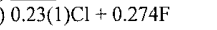 & $3 / 4$ & $-1 / 4$ & $0.165(1)$ & $1.8(2)$ \\
\hline$O(11)$ & $0.35 \mathrm{~F}+0.650$ & $0.4377(2)$ & $-0.0053(2)$ & $0.8640(2)$ & $0.81(4)$ \\
\hline $\mathrm{H}(11)$ & $0.65 \mathrm{H}$ & $0.437(5)$ & $0.022(5)$ & $0.798(5)$ & $3.95^{*}$ \\
\hline
\end{tabular}

refined formula: $\mathrm{Ca}_{18.92} \mathrm{Na}_{0.08}\left(\mathrm{Al}_{10.40} \mathrm{Fe}_{1.24} \mathrm{Mg}_{1.03} \mathrm{Ti}_{0.33}\right) \mathrm{Si}_{17.90} \mathrm{O}_{69}(\mathrm{OH})_{5.2} \mathrm{~F}_{3.345} \mathrm{Cl}_{0.455}$ Note: $B_{\text {eq }}$ values shown with an asterisk were fixed in the refinement. Underlined occupants were fixed.

TABLE 3c. POSITIONAL PARAMETERS OF ATOMS, SITE POPULATIONS, AND $B_{\mathrm{eq}}$ VALUES FOR VESUVIANITE WHISKER Ves 4

\begin{tabular}{|c|c|c|c|c|c|}
\hline atom & occupancy & $x / a$ & $y / b$ & $z / c$ & $B_{\mathrm{eq}}\left[\AA^{2}\right]$ \\
\hline$Z(1)$ & $0.959(9) \mathrm{Si}$ & $3 / 4$ & $1 / 4$ & 0 & $0.27(3)$ \\
\hline$Z(2)$ & $\mathrm{Si}$ & $0.54102(6)$ & $0.18107(7)$ & $0.8712(1)$ & $0.47(2)$ \\
\hline$Z(3)$ & $\mathrm{Si}$ & $0.65053(7)$ & $-0.08210(7)$ & $0.6346(1)$ & $0.58(2)$ \\
\hline$X(1)$ & $\mathrm{Ca}$ & $3 / 4$ & $1 / 4$ & $3 / 4$ & $0.70(3)$ \\
\hline$X(2)$ & $\mathrm{Ca}$ & $0.68867(5)$ & $0.04317(5)$ & $0.87948(8)$ & $0.64(1)$ \\
\hline$X(3)$ & $\mathrm{Ca}$ & $0.40109(5)$ & $0.17846(5)$ & $0.61392(8)$ & $0.93(1)$ \\
\hline$X(4)$ & $\underline{0.46 \mathrm{Ca}+0.04 \mathrm{Na}}$ & $3 / 4$ & $-1 / 4$ & $0.8645(6)$ & $1.55(9)$ \\
\hline$Y(1)$ & $0.5 \mathrm{Fe}$ & $3 / 4$ & $-1 / 4$ & $0.9378(4)$ & $1.60(8)$ \\
\hline$Y(2)$ & $\mathrm{Al}$ & $1 / 2$ & 0 & $1 / 2$ & $0.52(2)$ \\
\hline \multirow[t]{2}{*}{$Y(3)$} & $0.857(5) \mathrm{Al}+0.013(5) \mathrm{F}$ & & & & \\
\hline & $+0.108 \mathrm{Mg}+0.0225 \mathrm{Ti}$ & $0.61268(7)$ & $0.37910(7)$ & $0.8736(1)$ & $0.43(2)$ \\
\hline$O(1)$ & & $0.7196(2)$ & $0.3275(2)$ & $0.9147(3)$ & $0.58(4)$ \\
\hline$O(2)$ & & $0.6173(2)$ & $0.1593(2)$ & $0.7788(2)$ & $0.66(4)$ \\
\hline$O(3)$ & & $0.5497(2)$ & $0.2789(2)$ & $0.9234(2)$ & $0.57(4)$ \\
\hline$O(4)$ & & $0.5626(2)$ & $0.1065(2)$ & $0.9698(2)$ & $0.52(5)$ \\
\hline$O(5)$ & & $0.6699(2)$ & $0.0159(2)$ & $0.6773(2)$ & $0.79(5)$ \\
\hline$O(6)$ & & $0.7293(2)$ & $-0.1171(2)$ & $0.5594(2)$ & $1.12(5)$ \\
\hline$O(7)$ & & $0.4441(2)$ & $0.1746(2)$ & $0.8226(3)$ & $0.74(4)$ \\
\hline$O(8)$ & & $0.5907(2)$ & $-0.0609(2)$ & $0.9346(2)$ & $0.58(4)$ \\
\hline$O(9)$ & & $0.6425(2)$ & $-0.1425(2)$ & $3 / 4$ & $0.99(5)$ \\
\hline$O(10 A)$ & 0.50 & $3 / 4$ & $-1 / 4$ & $0.111(1)$ & $0.6(2)$ \\
\hline$O(10 B)$ & $0.2 \mathrm{Cl}+0.25 \mathrm{~F}$ & $3 / 4$ & $-1 / 4$ & $0.1658(9)$ & $1.5(2)^{*}$ \\
\hline$O(11)$ & $0.35 \mathrm{~F}+0.65 \mathrm{O}$ & $0.4378(2)$ & $-0.0056(2)$ & $0.8637(2)$ & $0.78(4)$ \\
\hline$H(11)$ & $0.65 \mathrm{H}$ & $0.433(5)$ & $0.019(5)$ & $0.797(5)$ & $3.95^{*}$ \\
\hline
\end{tabular}

refined formula: $\mathrm{Ca}_{18,92} \mathrm{Na}_{0.08}\left(\mathrm{Al}_{10,86} \mathrm{Fe}_{1,10} \mathrm{Mg}_{0,87} \mathrm{Ti}_{10.18}\right) \mathrm{Si}_{17,92} \mathrm{O}_{69}(\mathrm{OH})_{5,2} \mathrm{~F}_{3,3} \mathrm{Cl}_{0,4}$

Note: $B_{\text {eq }}$ values shown without a standard deviation marked by an asterisk were fixed in the refinement. $B_{\mathrm{eq}}$ values shown with a standard deviation marked by an asterisk were refined isotropically. Underlined occupants were fixed. 


\section{Discussion}

Although our vesuvianite whiskers represent a late stage and therefore a rather low-temperature crystallization $\left(<350^{\circ} \mathrm{C}\right.$, see below), the structure displays longrange-disordered strings, leading to $P 4 / n n c$ space-group symmetry. Up to now, vesuvianite with $P 4 / n n c$ spacegroup symmetry was considered characteristic of hightemperature formation. The observation of only one very weak reflection violating $P 4 / n n c$ symmetry may be due to minor low-symmetry domains within the crystal studied. The structure refinement led to excellent agreement between site occupancies (Tables 3a-c) and the chemical composition determined by analysis (Table 2). Only $\mathrm{Mg}, \mathrm{Ti}$, and $\mathrm{Na}$ concentrations were taken from analytical data, and the refined Fe occupancy relates to $\mathrm{Fe}$ and $\mathrm{Mn}$, which cannot be distinguished owing to the similarity in scattering factors.

The crystals studied are unusual in the high fluorine and moderate chlorine content, which is in contrast to low-symmetry $(P 4 / n$ and $P 4 n c)$ vesuvianite (Ohkawa
1994). In (F, Cl, B)-poor low-symmetry vesuvianite, periodic strings $\mathrm{O}(10), X^{\prime}(4), Y^{\prime}(1)-\mathrm{O}(10)-\mathrm{H} \ldots$ along the four-fold axis are linked to rods by hydrogen bonds (intra-rod order). In addition, laterally adjacent rods possess long-range order, and the kind of long-range order determines whether the space group is either polar $(P 4 n c)$ or nonpolar $(P 4 / n)(e . g .$, Allen \& Burnham 1992, Armbruster \& Gnos 2000a). In high-symmetry $P 4 / n n c$ vesuvianite, there may be two different origins of the string disorder: 1) the string periodicity within a rod is disturbed (intra-rod disorder), e.g., by intercalation of a reversed string, thus long-range ordered rods cannot occur, or 2) each rod is ordered (intra-rod order), but long-range order (from rod to rod) is not developed. If significant concentrations of $\mathrm{F}$, and even more importantly $\mathrm{Cl}$, are incorporated into the strings, intra-rod disorder could be initiated during crystal growth (Groat et al. 1992b, Ohkawa 1994).

Because the three crystals have a very similar structure, we will discuss crystal Ves 1 in most detail, as it is representative of the others. In Ves 1 , the half-occupied

TABLE 5. SELECTED INTERATOMIC DISTANCES FOR THREE SAMPLES OF VESUVIANITE WHISKERS

\begin{tabular}{|c|c|c|c|c|c|c|c|c|c|}
\hline & & Ves 1 & Ves 2 & Ves 4 & & & Ves 1 & Ves 2 & Ves 4 \\
\hline \multirow[t]{2}{*}{$Z(1)$} & $-O(1)$ & $(4 \times) 1.642(2)$ & $1.636(3)$ & $1.637(3)$ & $X(3)$ & $-O(3)$ & $2.443(2)$ & $2.437(3)$ & $2.439(3)$ \\
\hline & & & & & & $-O(6)$ & $2.508(2)$ & $2.521(3)$ & $2.509(3)$ \\
\hline \multirow[t]{4}{*}{$Z(2)$} & $-O(2)$ & $1.641(2)$ & $1.643(3)$ & $1.643(3)$ & & $-O(7)$ & $2.360(2)$ & $2.360(3)$ & $2.356(3)$ \\
\hline & $-O(3)$ & $1.643(2)$ & $1.643(3)$ & $1.643(3)$ & & $-O(7)$ & $2.494(2)$ & $2.495(3)$ & $2.490(3)$ \\
\hline & $-O(4)$ & $1.675(2)$ & $1.672(3)$ & $1.673(3)$ & & $-O(7)$ & $2.550(2)$ & $2.544(3)$ & $2.548(3)$ \\
\hline & $-O(7)$ & $1.614(2)$ & $1.610(3)$ & $1.612(3)$ & & $-O(8)$ & $2.595(2)$ & $2.584(3)$ & $2.581(3)$ \\
\hline \multirow{2}{*}{\multicolumn{2}{|c|}{ Mean }} & 1.643 & 1.642 & 1.643 & & $-O(10 A)$ & $2.5921(6)$ & $2.606(1)$ & $2.594(1)$ \\
\hline & & & & & & $-O(10 B)$ & $2.657(2)$ & $2.671(3)$ & $2.664(3)$ \\
\hline \multirow[t]{4}{*}{$Z(3)$} & $-O(5)$ & $1.636(2)$ & $1.631(3)$ & $1.630(3)$ & & $-O(11)$ & $2.438(2)$ & $2.431(3)$ & $2.440(3)$ \\
\hline & $-O(6)$ & $1.602(2)$ & $1.598(3)$ & $1.604(3)$ & Mean & $O(10 \mathrm{~A})$ & 2.498 & 2.497 & 2.495 \\
\hline & $-O(8)$ & $1.619(2)$ & $1.623(3)$ & $1.618(3)$ & Mean & $O(10 B)$ & 2.506 & 2.505 & 2.503 \\
\hline & $-O(9)$ & $1.655(1)$ & $1.655(2)$ & $1.655(2)$ & & & & & \\
\hline \multirow[t]{2}{*}{ Mean } & & 1.628 & 1.627 & 1.627 & $X^{\prime}(4)$ & $-O(6)$ & $(4 \times) 2.297(2)$ & $2.278(4)$ & $2.271(4)$ \\
\hline & & & & & & $-O(9)$ & $(4 \times) 2.680(2)$ & $2.698(4)$ & $2.718(5)$ \\
\hline \multirow[t]{2}{*}{$X(1)$} & $-O(1)$ & $(4 \times) 2.328(2)$ & $2.330(3)$ & $2.331(3)$ & & $-O(10 A)$ & $2.94(1)$ & $2.82(2)$ & $2.91(2)$ \\
\hline & $-O(2)$ & $(4 \times) 2.519(2)$ & $2.520(3)$ & $2.516(3)$ & Mean & $O(10 \mathrm{~A})$ & 2.539 & 2.525 & 2.541 \\
\hline \multicolumn{2}{|c|}{ Mean } & 2.424 & 2.425 & 2.424 & Mean & $O(6), O(9)$ & 2.489 & 2.488 & 2.495 \\
\hline \multirow[t]{8}{*}{$X(2)$} & $-O(1)$ & $2.488(2)$ & $2.492(3)$ & $2.494(3)$ & $Y^{\prime}(1)$ & $-O(6)$ & $(4 \times) 2.097(2)$ & $2.088(3)$ & $2.087(3)$ \\
\hline & $-O(2)$ & $2.432(2)$ & $2.435(3)$ & $2.424(3)$ & & $-O(10 A)$ & $2.00(1)$ & $1.94(2)$ & $2.04(2)$ \\
\hline & $-O(3)$ & $2.369(2)$ & $2.372(3)$ & $2.378(3)$ & Mean & & 2.078 & 2.058 & 2.078 \\
\hline & $-O(4)$ & $2.446(2)$ & $2.441(3)$ & $2.434(3)$ & & & & & \\
\hline & $-O(5)$ & $2.336(2)$ & $2.333(3)$ & $2.332(3)$ & $Y(2)$ & $-O(4)$ & $(2 \times) 1.950(2)$ & $1.949(3)$ & $1.950(3)$ \\
\hline & $-O(5)$ & $2.425(2)$ & $2.426(3)$ & $2.436(3)$ & & $-O(8)$ & $(2 \times) 1.868(2)$ & $1.857(3)$ & $1.862(3)$ \\
\hline & $-O(6)$ & $2.887(2)$ & $2.891(3)$ & $2.884(3)$ & & $-O(11)$ & $(2 \times) \underline{1.873(2)}$ & $1.872(2)$ & $1.875(3)$ \\
\hline & $-O(8)$ & $2.319(2)$ & $2.318(3)$ & $2.310(3)$ & Mean & & 1.897 & 1.893 & 1.896 \\
\hline \multirow[t]{8}{*}{ Mean } & & 2.463 & 2.464 & 2.462 & & & & & \\
\hline & & & & & $Y(3)$ & $-O(1)$ & $1.909(2)$ & $1.908(3)$ & $1.903(3)$ \\
\hline & & & & & & $-O(2)$ & $1.897(2)$ & $1.887(3)$ & $1.892(2)$ \\
\hline & & & & & & $-O(3)$ & $1.939(2)$ & $1.932(3)$ & $1.927(3)$ \\
\hline & & & & & & $-O(4)$ & $2.055(2)$ & $2.058(3)$ & $2.057(3)$ \\
\hline & & & & & & $-O(5)$ & $1.960(2)$ & $1.962(3)$ & $1.949(3)$ \\
\hline & & & & & & $-O(11)$ & $1.901(2)$ & $1.903(3)$ & $1.897(3)$ \\
\hline & & & & & Mean & & 1.944 & 1.942 & 1.938 \\
\hline
\end{tabular}

Note: $O(10 \mathrm{~A})$ and $\mathrm{O}(10 \mathrm{~B})$ are each half-occupied. The distances are quoted in $\AA$. 
anion sites $\mathrm{O}(10 \mathrm{~A})$ and $\mathrm{O}(10 \mathrm{~B})$ are separated by 0.62 $\AA$. The site $\mathrm{O}(10 \mathrm{~A})$ is occupied by oxygen. $\mathrm{O}(10 \mathrm{~B})$ is partially occupied by $\mathrm{F}$ and $\mathrm{Cl}$ and displays pronounced disorder along the four-fold axis $\left(U_{33}>U_{11}\right)$, which is easily explained by occupancy of two anions $(\mathrm{Cl}, \mathrm{F})$ of different size. The longer $\mathrm{O}(10 \mathrm{~A})$ to $\mathrm{O}(10 \mathrm{~B})$ distance is $2.66 \AA$, the $\mathrm{O}(10 \mathrm{~A})$ to $\mathrm{O}(10 \mathrm{~A})$ distance is $3.28 \AA$, and the $\mathrm{O}(10 \mathrm{~B})$ to $\mathrm{O}(10 \mathrm{~B})$ distance is $2.04 \AA$. These distances indicate that occupancy of adjacent $\mathrm{O}(10 \mathrm{~B})$ sites is not possible because the separation is too short. There is the presumption in the refinement model that $\mathrm{O}(10 \mathrm{~A})$ and $\mathrm{O}(10 \mathrm{~B})$ are both half occupied. In reality, we cannot exclude that the occupancy of $\mathrm{O}(10 \mathrm{~A})$ is higher than that of $\mathrm{O}(10 \mathrm{~B})$. If this is the case, we have to consider adjacent $\mathrm{O}(10 \mathrm{~A}), \mathrm{O}(10 \mathrm{~A})$ and $\mathrm{O}(10 \mathrm{~A}), \mathrm{O}(10 \mathrm{~B})$ pairs. $\mathrm{O}(10 \mathrm{~B})$ shows regular distances to $X(3)$ of $4 \times 2.66 \AA$, but the distance to $Y^{\prime}(1), 2.62 \AA$, appears too long for five-coordinated $\mathrm{Fe}^{2+}$ or $\mathrm{Fe}^{3+}$. On the other hand, $\mathrm{O}(10 \mathrm{~A})$, half occupied by oxygen, displays a reasonable distance of $2.00 \AA$ to $Y^{\prime}(1)$ and $4 \times 2.59 \AA$ to $X(3)$.
Furthermore, O(10A) exhibits also a distance of $2.94 \AA$ to $X^{\prime}(4)$, which could suggest that $\mathrm{O}(10 \mathrm{~A})$ partially contributes to the Ca coordination at $X^{\prime}(4)$.

In discussing intra-string disorder, most chemical and structural data (occupancies) suggest that $Y^{\prime}(1)$ and $X^{\prime}(4)$ have nearly identical populations (Groat et al. 1992a). For stoichiometric vesuvianite, one would expect a bulk $X: Y$ ratio of $19: 13=1.4615$. However, the average $X: Y$ ratio in the three whiskers is 1.4354 (Table 2), suggesting an excess of $Y$ cations. Such $Y$ excess vesuvianite with bulk $X: Y$ as low as 1.352 was described by Groat et al. (1994), where the excess cations are positioned at interstitial sites $T(1)$ and $T(2)$. In particular, partial occupancy of the $T(1)$ position would require (Groat et al. 1994) partial vacancies on $X(3)$. Groat et al. (1994) did not refine the occupancy of $X(3)$, but their structural data show a direct correlation between electron density at $T(1)$ and the isotropic displacement parameter of $X(3)$. An increased displacement parameter for $X(3)$ could be interpreted to have too high
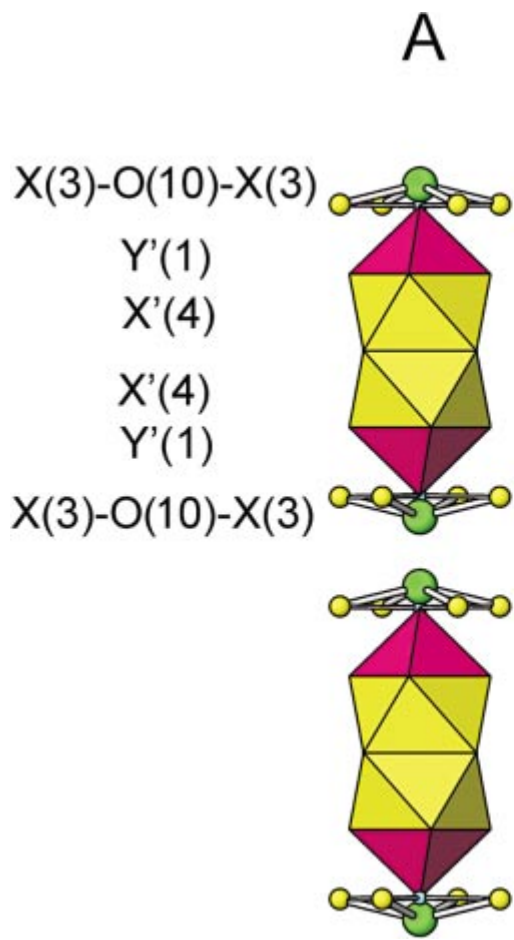

B
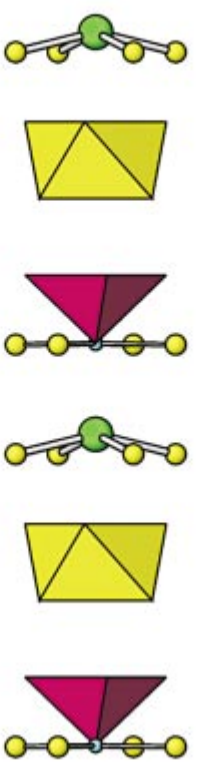

C
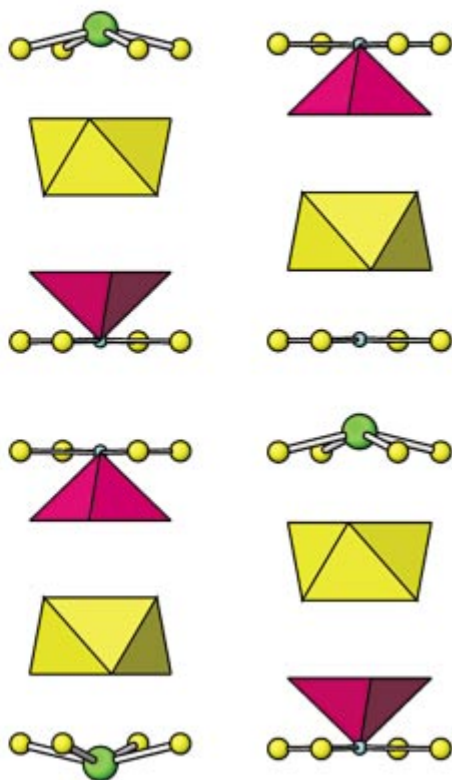

FIG. 5. A. In the vesuvianite structure, there are four cation positions, $Y^{\prime}(1), X^{\prime}(4), X^{\prime}(4), Y^{\prime}(1)$, that are aligned parallel to the four-fold axes. Site $Y^{\prime}(1)$ is five-coordinated (square pyramid), whereas $X^{\prime}(4)$ is eight-coordinated (dodecahedron). Adjacent polyhedra are face-sharing, so that for electrostatic reasons only each second polyhedron is occupied. Such occupied polyhedra form so-called strings terminated by $\mathrm{O}(10)$ sites. Atom $\mathrm{O}(10)$ also bonds $(4 \times)$ to $X(3)$ (small yellow spheres). In $(\mathrm{F}, \mathrm{Cl})$ rich vesuvianite, $\mathrm{O}(10)$ is split into $\mathrm{O}(10 \mathrm{~A})$, which is preferentially occupied by $\mathrm{O}$ (small blue sphere) and $\mathrm{O}(10 \mathrm{~B})$, which is occupied by $\mathrm{F}$ or $\mathrm{Cl}$ (large green sphere). B. Sequence of two periodic polar strings. C-D. Examples of string disorder causing intra-rod disorder (for discussion, see text). 
a scattering power assigned to $X(3)$, leading to the artifact that the electron probability cloud around $X(3)$ is expanded until the assumed electron-density is satisfied. Normalization of analytical data on the basis of $18 \mathrm{Si}$ thus should lead to a deficit of $X$ cations $(<19)$ and to an excess of $Y$ cations (>13), as shown by Groat $e t$ al. (1994), and to a much lesser extent, by our analytical results (Table 2). Only our crystal Ves 1 shows low occupancy of $T(1)$, to the extent of 0.8 epfu (electrons per formula unit), whereas Groat et al. (1994) determined the maximum of 10.4 epfu on $T(1)$ for their crystal N3.

A unit of two polar strings in $(\mathrm{F}, \mathrm{Cl})$-rich vesuvianite (Fig. 5) has the sequence $\mathrm{O}(10 \mathrm{~B}), X^{\prime}(4), Y^{\prime}(1)-$ $\mathrm{O}(10 \mathrm{~A}) \ldots$ There are two possible types of nonpolar string domains (Fig. 5) that may disturb intra-rod order: $\mathrm{O}(10 \mathrm{~B}), X^{\prime}(4), Y^{\prime}(1)-\mathrm{O}(10 \mathrm{~A}), \mathrm{O}(10 \mathrm{~A})-Y^{\prime}(1), X^{\prime}(4)$, $\mathrm{O}(10 \mathrm{~B})$ and $\mathrm{O}(10 \mathrm{~A})-Y^{\prime}(1), X^{\prime}(4), \mathrm{O}(10 \mathrm{~A}), \mathrm{O}(10 \mathrm{~B})$, $X^{\prime}(4), Y^{\prime}(1)-\mathrm{O}(10 \mathrm{~A})$. In this latter domain, the two adjacent $\mathrm{O}(10)$ positions cannot be of $\mathrm{O}(10 \mathrm{~B})$ type (too short, in view of a separation of $2.04 \AA$ ) but must be of $\mathrm{O}(10 \mathrm{~A})$ and $\mathrm{O}(10 \mathrm{~B})$ types if we allow, as an exception, that the population of $\mathrm{O}(10 \mathrm{~A})$ may be higher than the one of $\mathrm{O}(10 \mathrm{~B})$. Any bond-valence arguments questioning insufficient bonding of $\mathrm{O}(10 \mathrm{~A})$ adjacent to $X^{\prime}(4)$ can be rebutted by assuming that minor $\mathrm{OH}$ or $\mathrm{F}$ replaces $\mathrm{O}$ at $\mathrm{O}(10 \mathrm{~A})$. The IR spectrum (Fig. 4) displays a weak but broadened absorption at $3203 \mathrm{~cm}^{-1}$, which Groat $e t$ $a l$. (1995) assigned (their band $\mathrm{J}$ ) to $\mathrm{OH}$ at $\mathrm{O}(10)$. This $\mathrm{OH}$ is linked to $\mathrm{Fe}$ at $Y^{\prime}(1)$ and forms a hydrogen bond to $\mathrm{F}$ at adjacent $\mathrm{O}(10)$. Thus, our structural model with only $\mathrm{O}$ at $\mathrm{O}(10 \mathrm{~A})$ is overly simplified. The above discussion indicates that there is evidence for intra-rod disorder in vesuvianite with high $(\mathrm{F}, \mathrm{Cl})$ occupancy at $\mathrm{O}(10)$, even for the ideal value $X^{\prime}(4): Y^{\prime}(1)=1$.

The other position for potential F-for-OH substitution is $\mathrm{O}(11)$. This site shares a common corner of the edge-connected $Y(2), Y(3)$ octahedra. If $\mathrm{O}(11)$ is occupied by $\mathrm{OH}$, it forms bifurcated hydrogen bonds with two O(7) atoms as acceptors (Lager et al. 1999) with $\mathrm{O}(11)$ - O(7) distances of 2.784(4) and 2.934(4) $\AA$, respectively. In Ves 1, these distances are 2.832(2) and 2.959 (2) $\AA$, respectively. Owing to the bifurcated character, the hydrogen bonds are rather weak, and a disturbing influence of the arrangement due to F-for-OH substitution is not expected (Lager et al. 1999). Groat $e t$ al. (1992b) did not observe any increase in isotropic displacement parameters nor in anisotropy of displacement parameters for either $\mathrm{O}(11)$ or $\mathrm{O}(7)$ with increasing bulk F-content. However, Groat et al. (1992b) refined the $\mathrm{O}(11)$ position with the scattering power of oxygen and thus underestimated the true electron density by ignoring the possible influence of $\mathrm{F}$ on $\mathrm{O}(11)$. Disregard of $\mathrm{F}$ on $\mathrm{O}(11)$ led to the artifact that $U_{\text {iso }}$ of Groat et al. (1992b) decreased with increasing F-for$\mathrm{OH}$ substitution. In other words, the assumption of too low a scattering power leads to a volume reduction of the electron probability cloud.
The structure refinements of our three whiskers indicate $c a .5 \%$ vacancies at the orthosilicate site $Z(1)$, but not at the orthosilicate $Z(2)$ site and disilicate $Z(3)$ unit. This could simply be an artifact due to a high correlation (ca. $70 \%)$ between occupation and displacement parameter, but it could also indicate either minor hydrogarnet-like substitution $\left(\mathrm{O}_{4} \mathrm{H}_{4} \rightarrow \mathrm{SiO}_{4}\right)$ or a light element (e.g., B) partially replacing $\mathrm{Si}$. The average Z(1) - O distance, ca. $1.640 \AA$, is in the same range as found for other vesuvianite crystals reported in the literature (Groat et al. 1992a). However, the low concentration of vacancies does not suggest any influence on average bond-distances. Furthermore, electron-microprobe analyses cannot give a reliable answer to this problem because vesuvianite is nonstoichiometric, and there is no general procedure for normalization of analytical data in the calculation of a formula.

Electron-microprobe analyses (Table 2) indicate $c a$. 0.2 apfu $\mathrm{B}=1$ epfu for the three analyzed whiskers. A corresponding electron-density $(0.8 e p f u)$ was only found at $T(1)$ for crystal Ves 1 . However, such low concentrations of B are difficult to resolve, in particular from diffraction data (sealed tube) collected on very small crystals. The IR spectrum (Fig. 4) displays a sharp absorption at $3560 \mathrm{~cm}^{-1}$, with subordinate bands at 3626 and $3422 \mathrm{~cm}^{-1}$. These bands are characteristic of both fluorine-bearing crystals with $\mathrm{F}$ on $\mathrm{O}(11)$ and boronbearing vesuvianite where $\mathrm{B}$ occupies the interstitial $T(1)$ site (Groat et al. 1995).

\section{Conditions of Growth and Mechanism of Formation of the Vesuvianite Whiskers}

Structural and morphological data for vesuvianite (Goldschmidt 1918, Allen \& Burnham 1992, Armbruster \& Gnos 2000a, b) suggest that whiskers of vesuvianite are anomalous. This peculiar habit is related to specific conditions and mechanism of growth. Vesuvianite whiskers in cavities of altered magnesian skarn crystallized at a low activity of $\mathrm{CO}_{2}$ and at P-T conditions corresponding to the prehnite-pumpellyite facies (Galuskin \& Mokhov 1991). The observed mutual relations between vesuvianite whiskers and diopside (Figs. 2c, e) indicate that the whiskers formed almost simultaneously with zones in late diopside enriched in $\mathrm{Mn}$ and with diopside whiskers (Galuskin \& Mokhov 1991). Investigation of different generations and morphological forms of diopside in skarn cavities demonstrates that crystallization of early long-prismatic diopside began near $480^{\circ} \mathrm{C}$. Later, whiskers of diopside formed at a temperature below $350^{\circ} \mathrm{C}$, where the $\mathrm{pH}$ of the solution changed and kinetic factors began to play a deciding role (Galuskin \& Mokhov 1991). Whiskers of diopside and vesuvianite are not found together. Vesuvianite whiskers formed preferentially on those spots where grossular dissolved and where the solution became locally enriched in $\mathrm{Al}$. 
Morphology and crystal habit are determined by the anisotropy of growth rates for individual faces depending on both external and internal factors. Vesuvianite whiskers, elongate along [001], are bounded by the $\{100\}$ and $\{110\}$ prism faces and terminated by the $\{001\}$ pinacoid face (Fig. 2f). Faces of simple forms with the highest growth-rates have the tendency to "die off" and finally to disappear (Lemmlein 1973). For geometrical reasons, the $\{001\}$ pinacoid faces cannot "die off" in spite of their rapid growth.

Prismatic faces are smooth, whereas the pinacoid face possesses a rough, vicinal surface (Fig. 2f), demonstrating the differences in growth mechanism. Slow growth of $\{110\}$ and $\{100\}$ faces is caused by adsorption of surface-active substances poisoning the growth steps. Increased concentrations of manganese were found in the diopside whiskers as well as in the vesuvianite whiskers. Consequently, Mn could be interpreted as the substance poisoning $\{110\}$ and $\{100\}$ surfaces (Table 2, Fig. 3, Galuskin \& Mokhov 1991). Point defects forming as a result of substitutions at the channel positions along the 4-fold axis: $Y^{\prime}(1), X^{\prime}(4), \mathrm{O}(10)$, for example $\mathrm{O}=\mathrm{Cl}, \mathrm{F}$, may be centers for rapid growth of layers on $\{001\}$ faces.

Under conditions of high supersaturation, layer-bylayer growth of crystal faces probably did not propagate by attachment of single atoms or molecules, but by nano-size clusters, which transformed on the crystal surface to two-dimensional units (Askhabov 2002). Fluorine is a complex-forming element. It is possible that the high rate of growth of vesuvianite whiskers is caused by participation of F-bearing complexes as building units. It is also quite probable that nuclei of hightemperature $P 4 / n n c$ vesuvianite persisted in solution for a long time and led to the crystallization of string-disordered vesuvianite after a rapid drop in temperature.

On the other hand, the geochemical character of the solution containing high contents of halogens at low $\mathrm{P}\left(\mathrm{H}_{2} \mathrm{O}\right)$ (hypabyssal rocks) led to preferential structural incorporation of high amounts of $\mathrm{F}$ and moderate amounts of $\mathrm{Cl}$ (Table 2, Fig. 3). In addition, at $\mathrm{T}$ less than $350-400^{\circ} \mathrm{C}$, high contents of halogens probably promoted the formation of rod-disordered vesuvianite. In contrast, rod-ordered $P 4 / n$ and $P 4 n c$ vesuvianites never contain considerable fluorine (Fitzgerald et al. 1992, Ohkawa 1994, Pavese et al. 1998, Paluszkiewich \& Zabinski 1999, Armbruster \& Gnos 2000a, b).

In summary, vesuvianite whiskers from skarns of Polar Yakutia seem to have formed under a kinetic regime of growth with a selective influence of surfaceactive substances (e.g., Mn) on growth rates by poisoning the prism faces. Growth of these faces progressed with a tangential layer mechanism without participation of a central screw dislocation. String- and rod-order in vesuvianite develops concomitantly with crystal growth. Thus the formation of rod-disordered low-temperature vesuvianite is most likely directed by the kinetics of the crystallization process and by the composition of the fluid, rather than by temperature.

\section{ACKNOWLEDGEMENT}

We thank Yuanming Pan, an anonymous referee, Associate Editor Edward S. Grew, and Editor Robert F. Martin for their constructive comments on this paper.

\section{REFERENCES}

Allen, F.M. \& Burnham, C.W. (1992): A comprehensive structure-model for vesuvianite: symmetry variations and crystal growth. Can. Mineral. 30, 1-18.

Antonova, I.A. \& Goylo, E.A. (1999): Typomorphism of vesuvianite from rodingite of Bazhenovskoye chrysotileasbestos deposit, central Urals. Vestnik Sankt-Peterburskogo Universiteta, Seriya 7, Geologiya, Geografiya, 2(14), 78-86 (in Russ.).

AREM, J.E (1973): Idocrase (vesuvianite) - a 250-year puzzle. Mineral. Rec. 4, 164-174.

Armbruster, T. \& GNos, E. (2000a): $P 4 / n$ and $P 4 n c$ long range ordering in low-temperature vesuvianites. Am. Mineral. 85, 563-569.

$\&$ (2000b): "Rod" polytypism in vesuvianite: crystal structure of a low-temperature $P 4 n c$ vesuvianite with pronounced octahedral cation ordering. Schweiz. Mineral. Petrogr. Mitt. 80, 109-116.

Dixon, R., Gutzmer, J., Hejny, C., Döbelin, N. \& Medenbach, O. (2002a): Manganvesuvianite and tweddillite, two new $\mathrm{Mn}^{3+}$-silicate minerals from the Kalahari manganese fields, South Africa. Mineral. Mag. 66, 137-150.

\& RichARDS, R.P. (2002b): Epitactic hedenbergite whiskers on babingtonite, a second occurrence from a Triassic basalt at Lincoln Park near Paterson, New Jersey, USA. Schweiz. Mineral. Petrogr. Mitt. 82, 2532.

Stalder, H.A., Gnos, E., Hofmann, B. \& HERWEGH, M. (2000c): Epitaxy of hedenbergite whiskers on babingtonite in Alpine fissures at Arvigo, Val Calanca, Grisons, Switzerland. Schweiz. Mineral. Petrogr. Mitt. 80, 285-290.

Askhabov, A.M. (2002): Quatarons, their peculiarities and role in crystallogenesis. Int. Mineral. Assoc., Programme Abstr. (Edinburgh), 112.

Bonev, I.K. (1993): Non-equilibrium highly anisometric crystals and whiskers of galena. Mineral. Mag. 57, 231-240.

ReICHe, M. \& MARINOv, M. (1985): Morphology, perfection and growth of natural pyrite whiskers and thin platelets. Phys. Chem. Minerals 12, 223-232. 
Chukhrov, F.V., Bonshtedt-Kupletskaya, E.M. \& SMOL'YANINOVA, N.N., eds. (1972): Minerals, Handbook. III(1). Silicates with Single and Double Silicon-Oxygen Tetrahedra. Nauka, Moscow, Russia (in Russ.).

EnRaf-Nonius (1983): Structure Determination Package $(S D P)$. Enraf-Nonius, Delft, The Netherlands.

Fitzgerald, S., Leavens, P.B. \& Nelen, J.A. (1992): Chemical variation in vesuvianite. Mineral. Petrol. 46, 163-178.

Galuskin, E.V. \& Golovanova, T.I. (1987): Genetic peculiarity of polychrome diopside crystals from skarn of Polar Yakutia. Zap. Vser. Mineral. Obshchest. 116(1), 64-72 (in Russ.).

\& Moкноv, A. (1991): Diopside from the skarns of Yakutia: evolution of habit and composition, genesis of whiskers. Archiw. Mineral. XLVII(1), 17-39.

\& WINIARSKI, A. (1997): Syngenetic whisker inclusions of pyrite in quartz; morphology, structure and composition. Neues Jahrb. Mineral., Monatsh., 229-240.

Gevargizov, E.I. (1977): Growth of Whiskers and Plate Crystals from Gases. Nauka, Moscow, Russia (in Russ.).

GoldschmidT, V.M. (1918): Atlas der Krystallformen 1. Carl Winters Universitätsbuchhandlung, Heidelberg, Germany.

Groat, L.A., Hawthorne, F.C. \& Ercit, T.S. (1992a): The chemistry of vesuvianite. Can. Mineral. 30, 19-48.

\& (1992b): The role of fluorine in vesuvianite: a crystal structure study. Can. Mineral. 30, 1065-1075.

$\&$ (1994): Excess $Y$-group cations in the crystal structure of vesuvianite. Can. Mineral. 32, 497-504.

\& GRICE, J.D. (1998): Wiluite $\mathrm{Ca}_{19}(\mathrm{Al}, \mathrm{Mg}, \mathrm{Fe}, \mathrm{Ti})_{13}(\mathrm{~B}, \mathrm{Al}, \square)_{5} \mathrm{Si}_{18} \mathrm{O}_{68}(\mathrm{O}, \mathrm{OH})_{10}$, a new mineral species isostructural with vesuvianite, from the Sakha Republic, Russian Federation. Can. Mineral. 36, 1301-1304.

LAger, G.A., SchultZ, A.J. \& ERCit, T.S (1996): X-ray and neutron crystal structure refinements of a boron-bearing vesuvianite. Can. Mineral.34, 1059-1070.

Rossman, G.R. \& ERCIT, T.S. (1995): The infrared spectroscopy of vesuvianite in the $\mathrm{OH}$ region. Can. Mineral. 33, 609-626.

Lager, G.A., Xie, Qianyen, Ross, F.K., Rossman, G.R, Armbruster, T., Rotella, F.J. \& Schultz, A.J. (1999): Hydrogen-atom positions in $P 4 / n n c$ vesuvianite. Can. Mineral. 37, 763-768.
Lemmlein, G.G. (1973): Morphology and Crystal Genesis. Nauka, Moscow, Russia (in Russ.).

LyAKHOVICH, V.V. (1954): New data for mineralogy of Wiluy deposit of achtarandite. Trudy Vostochno-sibirskogo filiala Akad. Nauk SSSR, Seria Geol., 1, 85-116 (in Russ.).

Maleev, M.N. (1971): Peculiarity and Genesis of Natural Thread-Like Crystals and its Aggregates. Nauka, Moscow, Russia (in Russ.).

McGee, J.J. \& Anovitz, L.M. (1996): Electron probe microanalysis of geological materials for boron. In Boron Mineralogy, Petrology and Geochemistry (E.S. Grew \& L.M. Anovitz, eds.). Rev. Mineral. 33, 771-788.

OhKawa, M. (1994): Crystal chemistry and structure of vesuvianite. J. Sci. Hiroshima Univ., Ser. C 10, 119-149.

PAluszkiewicz, C. \& Żabí́ski, W. (1999): NIR spectra of vesuvianite - a complex ortho-disilicate mineral. J. Molec. Struct. 480-481, 683-688.

Pavese, A., Prencipe, M., Tribaudino, M. \& Aagaard, S.S. (1998): X-ray and neutron single-crystal study of $P 4 / n$ vesuvianite. Can. Mineral. 36, 1029-1037.

PhilpotTs, A.R. (1992): Principles of Igneous and Metamorphic Petrology. Prentice Hall, Englewood Cliffs, New Jersey.

Plyusnina, L.P. \& LiKhoidov G.G. (1993): Vesuvianite stability in water and water - carbon dioxide fluids. Geochim. 5, 644-654 (in Russ.).

Pouchou, J.L. \& Pichoir, F. (1985): "PAP" ( $\phi \rho Z)$ procedure for improved quantitative microanalysis. In Microbeam Analysis - 1985. San Francisco Press, San Francisco, California (104-106).

Shabynin, L.I. (1974): Ore Deposits in the Magnesium Skarn Association. Nedra, Moscow, Russia (in Russ.).

SHELdRICK, G.M. (1997): SHELX-97, Program for Crystal Structure Determination. University of Göttingen, Göttingen, Germany.

Spiridonov, E.M., Barsukova, N.S. \& Antonov, A.A. (1996): Mineralogy of Rodingite from Bazhenovskoye Deposit of Chrysotile-Asbestos. Ural State Mining Academy, Yekaterinburg, Russia (in Russ.).

ŻABIŃSKI, W.\& PALUSZKIEWICZ, C. (1994): Infrared spectroscopic evidence of ordering in the vesuvianite structure. Mineral. Polon. 25(1), 51-58.

Received February 7, 2003, revised manuscript accepted June 9, 2003. 